\title{
The Proprietary Foundations of Corporate Law
}

\author{
John Armour ${ }^{*}$ and Michael J. Whincop ${ }^{* *}$
}

John Armour

Trinity Hall

Cambridge CB2 1TJ

Phone +44 1223332550

Fax +44 1223332537

j.armour@cbr.cam.ac.uk
The late Michael J. Whincop

formerly Faculty of Law

Griffith University

Nathan Qld 4111

Australia

\footnotetext{
* Faculty of Law and Centre for Business Research, Cambridge University.

** Formerly Faculty of Law and Key Centre for Ethics, Law, Justice \& Governance, Griffith University.

This paper is dedicated to the memory of Michael Whincop. Earlier drafts were circulated under the title 'The Proprietary Structure of Corporate Law'. On behalf of Michael and myself, I thank Neil Campbell, Bruce Chapman, Brian Cheffins, Dan Cole, Matthew Conaglen, Simon Deakin, Alan Dignam, Luca Enriques, Nick Georgakopolous, Henry Hansmann, Henrik Lando, Amir Licht, Joe McCahery, Riz Mokal, Richard Nolan, James Penner, Larry Ribstein, Chris Riley, Erik Vermeulen and Adrian Walters for helpful comments and discussions on earlier drafts. I similarly thank participants at staff seminars at Griffith and Nottingham Universities, the $18^{\text {th }}$ EALE Conference at Vienna University and the W.G. Hart Workshop on Property and Corporate Law. The usual disclaimers apply.
} 


\title{
The Proprietary Foundations of Corporate Law
}

\begin{abstract}
Recent work in both the theory of the firm and of corporate law has called into question the appropriateness of analysing corporate law as 'merely' a set of standard form contracts. This article develops these ideas by focusing on property law's role in underpinning corporate enterprise. Rights to control assets are a significant mechanism of governance in the firm. Practical circumstances dictate that such rights must be shared. Property law protects the rights of co-owners against each other's opportunistic attempts to grant entitlements to third parties. At the same time, it uses a range of strategies to minimise the costs such protection imposes on third parties. The choice of strategy significantly affects coowners' freedom to customise their control-sharing arrangements. This theory is applied to give an account of the 'proprietary foundations' of corporate law, which has significant implications for the way in which the subject's functions are understood and evaluated.
\end{abstract}

JEL Codes: D23, G34, K11, K22

Keywords: theory of corporate law, shared ownership, property rights 


\section{Introduction}

For more than twenty-five years, corporate law scholarship has been dominatedwhether as first step or point of departure-by an economic model that views firms as complex sets of contracts. For those who subscribe to it, a widely perceived implication is that corporate law, being the body of rules which governs these complex contracts, is essentially a specialist branch of contract law. Consequently, the 'contractarian' theory of corporate law adopted key ideas from the law and economics of contracts. ${ }^{1}$

This contractarian view of corporate law has had many critics. ${ }^{2}$ A large number have been from perspectives external to the economic analysis of law. Some found the theory's dismissal of the significance of corporate personality to be unconvincing. ${ }^{3}$ Others objected to the normative emphasis given to economic efficiency by those deploying the theory, ${ }^{4}$ and arguments based upon it for the significance of 'shareholder value'.

Clearly, the economic theory of the firm does not provide a complete ontology of the corporation, whether the inquiry limits itself to legal discourse or is posed at a more general social level. Yet the economic theory of the firm has never sought to be anything other than instrumental. It attempts only to predict patterns of organisation and finance as responses to particular states of the world, and if successful, offers a

\footnotetext{
${ }^{1}$ The classic account is F.H. Easterbrook and D.R. Fischel, The Economic Structure of Corporate Law (Cambridge, MA: Harvard University Press, 1991). See also the symposium entitled 'Contractual Freedom and Corporate Law' (1989) 89 Colum LR 1395-1774. For application to English law, see B.R. Cheffins, Company Law: Theory, Structure and Operation (Oxford: Oxford University Press, 1997) and M.J. Whincop, An Economic and Jurisprudential Genealogy of Corporate Law (Aldershot: Ashgate, 2001).

${ }^{2}$ The classic critique is W.M. Bratton, 'The "Nexus-of Contracts" Corporation: A Critical Appraisal' (1989) 74 Cornell LR 407.

${ }^{3}$ See eg, S. Worthington, 'Shares and Shareholders: Property, Power and Entitlement: Part 1' (2001) 22 Co Law 258, 264.

${ }^{4}$ See eg, D. Millon, 'Theories of the Corporation' [1990] Duke LJ 201; L.E. Mitchell, 'The Cult of Efficiency' (1992) 71 Tex LR 217; J. Dine, 'Fiduciary Duties as Default Rules, European Influences and the Need for Caution in the Use of Economic Analysis' (1999) 20 Co Law 190.

${ }^{5}$ See eg, M.M. Blair, Ownership and Control: Rethinking Corporate Governance for the Twenty-First Century (Washington, DC: Brookings Institute, 1995); G. Kelly and J. Parkinson, 'The Conceptual Foundations of the Company: A Pluralist Approach' (1998) CFILR 174; P. Ireland, 'The Myth of Shareholder Ownership' (1999) 62 MLR 32.
} 
way of understanding when and why firms come into existence. For corporate lawyers applying this theory, the goal is to understand how particular patterns of corporate law may affect these processes, so as to inform debate about how best it might achieve regulatory or facilitative goals.

For scholars seeking to understand the functions performed by corporate law, the contractarian theory has proved a useful workhorse. ${ }^{6}$ However, even within this tradition, the limits of the 'contractarian' approach are now coming to be realised. Viewing corporate law merely as a set of 'standard forms' for business organisation yields the counter-intuitive implication that its significance for business may be trivial. $^{7}$ Commercial actors are perfectly capable of producing standard forms themselves and there seems no clear reason for thinking that, apart from in relation to the smallest firms, the state has a clear comparative advantage in supplying such terms. Yet comparative studies appear to demonstrate empirically the significance of corporate law for the functioning of capital markets. ${ }^{8}$ Something appears to be missing.

At the same time, economic theory has moved on from viewing firms simply as contracts to understanding them as combinations of contracts and productive assets, emphasising the significance of the allocation of property rights to those assets for the governance of the enterprise. ${ }^{9}$. Some have interpreted the new this as merely recharacterising the firm as a nexus of contracts about assets. This overlooks the important role of property law in facilitating the sharing of ownership by protecting the entitlements of co-owners against dealings by one of their number with third parties. More recently, a few scholars - most notably Hansmann and Kraakmann-

\footnotetext{
${ }^{6}$ There are too many works written in this genre to cite exhaustively. For an overview, see sources cited above, n 1. See also R.R. Kraakman et al, The Anatomy of Corporate Law (Oxford: Oxford University Press, 2004), in which much of the analysis builds upon contractarian scholarship.

${ }^{7}$ B.S. Black, 'Is Corporate Law Trivial?: A Political and Economic Analysis' (1990) 84 NW ULR 542.

${ }^{8}$ See R. La Porta et al., 'Legal Determinants of External Finance' (1997) 52 J Fin 1131. Cf. B.R. Cheffins, 'Law, Economics and History: Lessons from the UK's System of Corporate Governance', (2001) 1 JCLS 71; M. Roe, Political Determinants of Corporate Governance (2003).

${ }^{9}$ See generally O. Hart, Firms, Contracts, and Financial Structure (Oxford: Clarendon Press, 1995). See also R. Rajan and L. Zingales, 'Power in a Theory of the Firm' (1998) 113 QJ Econ 387. 'Governance' refers here to the set of constraints on how parties divide up the economic surplus generated within the firm: see L. Zingales, 'Corporate Governance' in P. Newman (ed.), The Palgrave Dictionary of Economics and the Law, Vol 1 (London: Macmillan, 1998), 497.
} 
have claimed that corporate law performs functions that go beyond simply supplying standard terms, suggesting that its more significant role is to partition property rights to assets used in productive enterprise, ${ }^{10}$ in a way that could not be replicated by private contract. However, in our view these contributions still understate the role of property law, ${ }^{11}$ and do not explain how their analyses relate to the new 'property rights' .. ${ }^{12}$

This article seeks to further progress to unifying economic and legal conceptions of property in relation to corporate law. We argue that the 'property rights' theory of the firm fails to distinguish between contracts about assets and the partition of property rights to assets. This distinction has functional significance: proprietary rights protect their holders' claims better than do contractual ones, thereby enabling their more effective use as governance mechanisms within the firm, but at the same time, create costs for third parties. The law must balance the goal of facilitating flexibility in partitioning of entitlements between participants in the firm, whilst at the same time minimising costs for third parties.

These issues are of course understood in general terms by theorists of property, but the full scope of their application to organisational law has yet to be appreciated. In particular, the use of legal categorisations (e.g. 'company law' or 'property law') tends to obscure the functionally similar roles played by different areas of law in relation to business enterprise. In particular, it has not been fully appreciated that agency law is, from a functional point of view, performing an identical function in relation to business enterprise as is 'property law' more narrowly defined. ${ }^{13}$ What is needed, therefore, is a more generalised functional account of the role played by

\footnotetext{
${ }^{10}$ H. Hansmann and R. Kraakman, 'The Essential Role of Organizational Law' (2000) 110 Yale LJ 387, 407-408. See also P.G. Mahoney, 'Contract or Concession? An Essay on the History of Corporate Law' (2000) 34 Ga LR 873; M. Blair, 'Locking in Capital: What Corporate Law Achieved for Business Organizers in the Nineteenth Century' (2003) 51 UCLA L Rev 387; P. Ireland, 'Property and Contract in Contemporary Corporate Theory' (2003) 23 LS 453.

${ }^{11}$ Hansmann and Kraakman, for example, claim that property law's only relevant contribution to organizational corporate-law is what they term 'affirmative asset partitioning': that is, preventing shareholders' personal creditors from executing against corporate assets: ibid 394-395.

$12=$

13 Similarly, aspects of the law(s) of trusts, secured credit, fraudulent conveyance and corporate insolvency law also perform a functionally similar role to the one we have that together permit participants to share entitlements to property in a way that binds third parties.
} 
property law. This serves two ends. First, it allows for the more generalised introduction of property law into economic theories of the firm. Secondly, it offers pointers as to which aspects of organisational law may be genuinely non-trivial.

The rest of the paper is structured as follows. In section two, we motivate the enquiry with an overview of the contractarian theory of the firm and the strength of the 'triviality' objection. Section three begins by showing that the new economic 'property rights' theory of the firm has to date failed to distinguish between contracts about assets and rights to assets, and hence is liable to the same triviality objection. It then shows how a lawyer's distinction between personal and proprietary rights can assist in overcoming this, and articulaes a general functional account of the law's role in relation to proprietary entitlements in organisational assets: that is, organisational co-ownership. The economic (functional) significance of this account is then explored. Section four shows how this functional understanding of organisational coownership maps onto English law. For reasons of space, the mapping is limited to corporate enterprise, but the functional account of co-ownership would map equally well onto any form of organisation.

Section five concludes by explaining the implications of the analysis for our understanding of what corporate law does and how it should be structured.

\section{The Contractarian Theory of Corporate Law and its Limitations}

As corporate law facilitates and regulates business firms, an account of its functions must be premised upon a theory that explains what a firm is and why it exists. These questions, first posed by Ronald Coase in $1937,{ }^{14}$ form the research agenda of the economic theory of the firm. Thus the theory of the firm is the starting point for functional accounts of corporate law.

Coase's answers focused on the costs of contracting. Parties involved in a firm interact with one another over long periods of time. The costs of producing many iterated spot contracts, or of one long-term contract covering all relevant contingencies, would be very high. Instead, it might be cheaper to grant authority to one party to make decisions about what should be done. For Coase, then, a 'firm' was characterised by an authority relation.

\footnotetext{
${ }^{14}$ R.H. Coase, 'The Nature of the Firm' (1937) 4 Economica 386.
} 


\subsection{The Contractarian Theory of the Firm}

In 1972, Alchian and Demsetz argued that Coase's notion of authority was misplaced. ${ }^{15}$ In their view, firms were no more than contracts. ${ }^{16}$ Whilst there were costs to writing the contracts which constituted the firm, these were only quantitatively, rather than qualitatively, different from those involved in writing longterm contracts between firms. The firm, then, was a special case of long-term contract. The second question shifted from 'why firms?' to 'why this type of contract?'

This shift in emphasis had been accompanied by developments in the economic theory of 'contracts' (intertemporal exchange). The new theory focused on the effects of 'asymmetric information' between contracting parties: both about their respective attributes before they entered into the relation, and about the quality of their performance (or the reasons for their non-performance) once the relation had been established. Under these circumstances, it would of course be very costly to 'police' performance, and hence parties would have an incentive to appropriate to themselves some of the gains from trade or to underinvest effort. Thus the theory of 'agency' contracts investigated how payments based on observable variables could be structured so as to give the party with the superior information an incentive not to shirk. Alchian and Demsetz put these problems at the core of their analysis of the firm. ${ }^{17}$ Shortly afterwards, Jensen and Meckling offered a positive theory of corporate finance based on the same premises. ${ }^{18}$ Together, these accounts offered a plausible answer to the question, 'why this type of contract'?

\footnotetext{
${ }^{15}$ A.A. Alchian and H. Demsetz, 'Production, Information Costs and Economic Organization' (1972) 62 Am Econ Rev 777.

${ }^{16}$ Susceptible either to the 'repeated spot contract', or the 'single long term' analysis. The 'authority' to which Coase referred was non-existent: employers were no more able to 'force' employees to do something against their will than anyone else. Rather, the employment relation was purely voluntary.

${ }^{17}$ They saw the distinguishing feature of a firm as team production: each individual is necessary for production to occur, but that it is not observable from the joint output how much effort each individual has been applying.

${ }^{18}$ M.C. Jensen and W.H. Meckling, 'Theory of the Firm: Managerial Behavior, Agency Costs, and Ownership Structure’ (1976) 3 J Fin Econ 305.
} 


\subsection{Contractarian Corporate law}

In what must have seemed a natural step, a generation of legal scholars applied this contractarian theory of the firm to corporate law: if firms were (complex) contracts, then corporate law was a (complex) branch of contract law.

In the late 1970s and early 1980s, law and economics scholars understood the role of contract law as filling 'gaps', which parties left in contracts because of the costs of negotiation and drafting, by supplying 'default' or 'boilerplate' terms. Drawing an analogy with standard form contracts, it was argued that such 'default rules' should be chosen according to what a majority of contracting parties 'would have wanted'- had they been able to specify their terms at zero cost. ${ }^{19}$ In effect, this viewed the default rules set out by the law as a form of public good. ${ }^{20}$ A related claim was that 'mandatory rules' - those which parties were unable to disapply by contract - were justifiable only by the presence of market failures. ${ }^{21}$ Easterbrook and Fischel's famous series of articles on corporate law coupled these ideas drawn from the early law and economics analysis of contract law with the insights of the agency costs theory of the firm, arguing that the principal function of corporate law was to supply default rules into the 'corporate contract'. ${ }^{22}$

\subsection{The Limitations of Contractarian Corporate law}

19 R.A. Posner and A.M. Rosenfeld, 'Impossibility and Related Doctrines in Contract Law: An Economic Analysis' (1977) 6 J Leg Stud 83; C. Goetz and R.E. Scott, 'The Limits of Expanded Choice: An Analysis of the Interactions Between Express and Implied Contract Terms' (1985) 75 Calif LR 261, 262-263.

\footnotetext{
${ }^{20}$ In order for such gap-filling to be efficient, the cost of supplying the term by the state must be less than the cost at which the parties can supply it themselves. It does not necessarily require that the state have a cost advantage over any given set of parties, but rather that a one-off supply of terms by the state be cheaper than the sum of the costs which parties would incur in order to supply such terms.

${ }^{21}$ See the discussion in Cheffins, above $\mathrm{n} 1,231-32$. The general scepticism about mandatory rules in the law and economics literature on contract law has endured: see A. Schwartz and R.E. Scott, 'Contract Theory and the Limits of Contract Law' (2003) 113 Yale LJ 541, 609-18; cf I. Ayres, 'Valuing Modern Contract Scholarship' (2003) 113 Yale LJ 881, 886-890.

${ }^{22}$ The corpus of their scholarship is synthesised in their book: Easterbrook and Fischel, above n 1. See also the 1989 symposium issue of the Columbia Law Review, above $\mathrm{n} 1$.
} 
In recent years, a number of internal weaknesses have become apparent in the 'contractarian' theory of corporate law. ${ }^{23}$ Subsequent developments in contract economics suggest that the function of legal 'default rules' may be much more limited than the contractarians imagined. ${ }^{24}$

First, it is now understood that the costs of drafting are not the only reason why parties might leave 'gaps' in their contracts. ${ }^{25}$ Another is the cost of enforcement. ${ }^{26}$ Where relevant information about performance is costly to 'verify' to a court, parties may prefer to rely on non-legal governance mechanisms to resolve the problem. $^{27}$ For a court to 'fill gaps' in such circumstances would be counterproductive.

Secondly, even if it is possible to identify 'gaps' generated solely by drafting costs, there is pessimism about whether legal 'default rules' really offer significant savings, save for the smallest enterprises. The potential economies of scale seem limited, given the wide variation in users' requirements, ${ }^{28}$ and even where they exist, it is plausible that they could equally be captured by 'standard forms' developed by

${ }^{23}$ See eg, D. Charny, 'Hypothetical Bargains: The Normative Structure of Contract Interpretation' (1991) 89 Michigan LR 1815; I. Ayres, 'Making a Difference: The Contractual Contributions of Easterbrook and Fischel' (1992) 59 U Chic LR 1391; A. Schwartz, 'Incomplete Contracts' in Newman, above $\mathrm{n} 9$, Vol 2, 277. For reasons of space, this article does not consider critiques based on viewpoints external to the economic analysis of law.

${ }^{24}$ See Schwartz and Scott, above n 212120, 592-608; E.A. Posner, 'Economic Analysis of Contract Law After Three Decades: Success or Failure?' (2003) 113 Yale LJ 829; cf Ayres, above n 212120, 890-892.

25 A. Schwartz, 'Relational Contracts in the Courts: An Analysis of Incomplete Agreements and Judicial Strategies’ (1992) 21 J Leg Stud 271, 278-281.

${ }^{26} \mathrm{~A}$ third is that one party prefers to keep information relevant to performance to themselves, so as to secure a lower price (I. Ayres and R. Gertner, 'Filling Gaps in Incomplete Contracts: A Theory of Default Rules' (1989) 99 Yale LJ 87). Whilst in theory courts may be able to overcome such 'strategic contractual incompleteness' with appropriately-designed 'penalty default rules', the appropriate choice of rule is such a complex and context-sensitive exercise that the chances of successfully operationalising the theory seem to be virtually nil. See I. Ayres and R. Gertner, 'Strategic Contractual Inefficiency and the Optimal Choice of Legal Rules' (1992) 101 Yale LJ 729, 765.

${ }^{27}$ For example, the desire to maintain an ongoing business relation that is valuable for both parties. See K. Eggleston, E.A. Posner and R. Zeckhauser, 'The Design and Interpretation of Contracts: Why Complexity Matters’ (2000) 95 NW ULR 91, 107-126.

${ }^{28}$ Black, above n 7, 557-558; Schwartz, above n 2323222, 282. 
professionals working in a particular field. ${ }^{29}$ There is no reason to think that almost all corporate terms could not be supplied in this fashion. The history of the development of the joint stock partnership in England prior to the Joint Stock Companies Act of 1844 is a case in point,,$^{30}$ another being the standard terms used in bond documentation. ${ }^{31}$ These weaknesses leave the contractarian theory offering at best a limited explanation of corporate law's function.

A died-in-the-wool contractarian might infer no more from these observations than corporate law is of little functional interest. However, recent comparative law and economics scholarship has suggested that the configuration of corporate laws may be associated with significant international differences in the development of stock markets and the financing of firms. To be sure, there are considerable difficulties with this literature, but at the very least it provokes about whether our contractarian may be missing something. One possibility (and there are doubtless others) is that the functioning of property (or property-like) ${ }^{32}$ law in relation to organisational enterprise may perform a non-trivial role.

\section{Property and the Firm}

\subsection{The Property Rights Theory of the Firm}

Indeed, economists have themselves started to augment the contractarian theory of the firm by reference to 'property rights'. Williamson and others influenced by organisational theory developed a more 'Coasean' account of the firm, emphasising

\footnotetext{
29 Easterbrook and Fischel themselves acknowledged this limitation in their argument: F.H. Easterbrook and D.R. Fischel, 'The Corporate Contract' (1989) 89 Colum LR 1416, 1444-1446.

${ }^{30}$ See P.L. Davies, Gower's Principles of Modern Company Law (London: Sweet \& Maxwell, $6^{\text {th }}$ ed, 1997), Ch 2; R. Harris, Industrializing English Law (Cambridge: Cambridge University Press, 2000), Ch 6; Mahoney, above n Error! Bookmark not defined.Error! Bookmark not defined.10. For empirical evidence as to the importance of practitioners' precedent manuals as 'standard forms', see M.J. Whincop, 'An Empirical Analysis of the Standardisation of Corporate Charter Terms: Opting out of the Duty of Care' (2003) 23 Int'l Rev L \& Econ 285.

${ }^{31}$ C.W. Smith and J.B. Warner, 'On Financial Contracting: An Analysis of Bond Covenants', (1979) 7 J Fin Econ 117; M. Kahan and M. Klausner, 'Standardization and Innovation in Corporate Contracting (Or “The Economics of Boilerplate”)' (1997) 83 Va LR 713.

32 This infelicitious term is used to deflect the lawyer's objection that the rules we discuss are not all found within the domain of 'property law' as defined in legal discourse.
} 
qualitative differences from market exchange. ${ }^{33}$ They saw firms as a response to the 'hold-up' costs arising from squabbles over the distribution of productive surplus, ${ }^{34}$ giving rise to transaction costs of productive activity over and above the ubiquitous costs of asymmetric information..$^{35}$

Of course, such hold-up problems may be ameliorated by contracts. However, a contractual solution will be 'incomplete' in the presence of uncertainty and asymmetric information. A promise to pay a fixed amount will mean the promisor must bear the risk that the production process fails, for whatever reason, to produce the expected surplus. A contingent promise will mean the promisee must be able to observe and verify to a court that failure to make the promised payments does not fall within the contractual exclusions.

Williamson argued that where the amounts at stake were large, it would be cheaper for one party simply to buy both assets and organise production itself, thereby avoiding the hold-up problem. ${ }^{36}$ These insights were formalised by Oliver Hart and his co-authors, giving rise to what has become known as the 'property rights' theory of the firm. ${ }^{37}$ A key result is the ability to explain the boundaries of the firm: that is,

33 B. Klein, R. Crawford and A.A. Alchian, 'Vertical Integration, Appropriable Rents, and the Competitive Contracting Process', (1978) 21 JL \& Econ 297; O.E. Williamson, The Economic Institutions of Capitalism (New York: Free Press, 1985); Hart, above n 9.

${ }^{34}$ Klein et al, ibid.

35 The relevant productive surplus is referred to by economists as 'quasi-rents' - namely, the supracompetitive profit generated by a processes that combines assets in a unique manner. Often such processes will require the assets to be customised, lowering their value in other uses. However, once assets have been customised, the owner may be vulnerable to 'hold-up' by other parties whose cooperation or assets are required for the productive process. If other party refuses to share as much of the productive surplus as initially promised, the owner will be forced to accept this if the asset is-because of customisation- even less valuable elsewhere.

${ }^{36}$ Williamson, above $\mathrm{n}$ 333331, 68-84. The allocation of ownership is of course not the only way in which parties can influence the shape of ex post bargaining over surplus. Important non-legal mechanisms include 'corporate culture' and social norms (see M.A. Eisenberg, 'Corporate Law and Social Norms' (1999) 99 Colum LR 1253; E.B. Rock and M.L. Wachter, 'Islands of Conscious Power: Law, Norms and the Self-Governing Corporation' (2001) 149 U Pa LR 1619). The current article is concerned with law's role in structuring control rights, so these issues will be left for consideration elsewhere.

${ }^{37}$ S. Grossman and O. Hart, 'The Costs and Benefits of Ownership: A Theory of Vertical and Lateral Integration' (1986) 94 J Pol Econ 691; O. Hart and J. Moore, 'Property Rights and the Nature of the Firm' (1990) 98 J Pol Econ 1119. Most of the results are synthesised in Hart, above n 9. 
when an asset will be owned as part of a co-specialised collection (within the firm), and when held separately with the governance of the relation between the two parties determined by contract (outside the firm).

The theory also seeks to explain various patterns of corporate finance, most notably the use of debt. ${ }^{38}$ The intuition here is that an entrepreneur seeking debt finance enters into a deal with the financing creditor that gives the creditor the power to take over the ownership of the assets should the entrepreneur default on the repayments. Thus, provided that the assets are worth more to the entrepreneur than the value of the outstanding repayments, this allocation of property rights elicits repayment without a court needing to determine anything other than whether or not default occurred. As such, it is an 'end-game' mechanism: a step that is only taken if the relationship between creditor and debtor is on the verge of breaking down. Its existence in the background, however, makes the debtor want to continue to keep the relationship on foot. ${ }^{39}$

The implications of this account for the theory of corporate law have not yet been fully developed. ${ }^{40}$ As a next step, it may be helpful to examine more closely the conception of 'property' employed in the literature.

\subsection{Property rights with undivided ownership}

The account of 'property rights' employed in the economic theory of the firm is reductionist, in keeping with economists' quest for analytic parsimony. ${ }^{41}$ 'Ownership' is defined as the entitlement to exercise 'residual rights of control'. 'Control' is significant because where contracts are incomplete, the power to direct how an asset

\footnotetext{
${ }^{38}$ O. Hart and J. Moore, 'Default and Renegotiation: A Dynamic Model of Debt' (1998) 113 QJ Econ 1.

${ }^{39}$ Similar logic can explain the relationship between managers and a (majority) outside shareholder. See Z. Fluck, 'Optimal Financial Contracting: Debt versus Outside Equity' (1998) 11 Review of Financial Studies 383.

40 Thus Pettet, after a careful review of the theory of the firm, concludes: 'It remains to be seen whether the difficult insights of [the property rights] theory will become as influential as those provided by the earlier ... analyses.' (B. Pettet, Company Law (Harlow: Pearson, 2001), 78).

41 'Occam's razor' is applied unflinchingly by economists, reasoning that a simpler theory is capable of more general application. See eg, F. Machlup, Methodology of Economics and Other Social Sciences (New York: Academic Press, 1978), 88-89, 401.
} 
is used ex post will make a difference to outcomes. ${ }^{42}$ 'Residual' implies that the rights to control cover all states of the world which are not specified by law or contract $e x$ ante. ${ }^{43}$ Residuarity matters because it is still possible to allocate residual rights even if specific directions about what should (not) be done in particular circumstances cannot be written or enforced.

This residuary essence of property rights is a point well understood by analytic lawyers. The classic explication is that of Honoré, describing the content of the package of legal entitlements known as 'ownership':

'Ownership comprises the right to possess, the right to use, the right to manage, the right to the income of the thing, the right to the capital, the right to security, the rights or incidents of transmissibility and absence of them, the prohibition of harmful use, liability to execution, and the incident of residuarity.' 44

Honoré emphasises that subject to restrictions imposed by law or contract, the 'owner' is the party who holds all the other rights which a person may enjoy as regards an asset. Thus the owner is at liberty to dictate the use, management, and alienation of the asset, and to use it to bond the performance of his contracts (what Honoré terms the 'incident of liability to execution'). Where undivided ownership is enjoyed by one person, the economists' accounts therefore have much in common with lawyers' understandings.

\subsection{Shared Control of Organisational Assets}

\footnotetext{
${ }^{42}$ This marks an important break from earlier economic theories, in which 'ownership' was equated with rights to 'residual income'. If complete contracts cannot be written, then party entitled to residual income will not necessarily receive this income, unless they also exercise residual control rights (Hart, above $\mathrm{n}$ 333331, 63-66.

${ }^{43}$ Hart, above n $\underline{3333} 31,30$.

${ }^{44}$ A.M. Honoré, 'Ownership' in A.G. Guest (ed), Oxford Essays in Jurisprudence (Oxford: Oxford University Press, 1961) 107, 113.
} 
Whilst thinking about property in terms of undivided ownership is adequate for a discussion of the boundaries of the firm (that is, whether a particular factor of production should be made or bought, and hence whether the associated capital assets to produce it should be owned by this firm or another), discussion of entitlements to control assets as part of a theory of governance between participants within a firm necessarily requires a conception of shared entitlements.

At this point, it might be helpful to articulate more precisely how entitlements to control organisational assets are typically parcelled up between participants in a firm. In legal terms, as we have seen, the notion of 'residual control rights' used in the economic 'property rights theory of the firm' equates to the contents of the bundle of entitlements that would together comprise 'ownership'. Our enquiry here is to show how these entitlements are parcelled out amongst participants in business firms across different states of the world: that is, who, and under what circumstances, can exercise these entitlements? This is a functional analysis, which cuts across the law's formal allocation of the entitlements of ownership to an artificial person in the case of corporate enterprise ${ }^{45}$ We begin by identifying as building blocks the sharing arrangements employed in simple forms business organisation, and work up to their combined application in larger organisations such as public companies. According to the property rights view of the firm, the structure of the allocation of control rights will respond to governance considerations: that is, it will be a mechanism for reducing the agency costs as between participants. ${ }^{46}$

Where a firm's physical assets consist of more than a relatively small portfolio, an entrepreneur will lack the time to make all the control decisions herself. ${ }^{47}$ Hence she will need to delegate responsibility for certain 'use decisions' (that is

\footnotetext{
45. Such a person cannot act save through the actions of its natural agents (Meridian Global Funds Management Asia Ltd v Securities Commission [1995] 2 A.C. 500, 506-507). Therefore our primary interest, from a functional standpoint, is in the circumstances under which such natural persons can exercise control in respect of the organisational assets.

46 This of course creates potential for counter-opportunism. Where contracts are incomplete, trust or norm-based mechanisms will be necessary to ensure that such decisions are taken in the interests of the co-owners as a whole. For accounts of the role of such non-legal standards against a backdrop of 'endgame' control rights enforceable in law, see S. Deakin and A. Hughes, 'Economic Efficiency and the Proceduralisation of Company Law' [1999] 3 CFILR 169 and Rock and Wachter, above n $36 \underline{36} 34$.

${ }^{47}$ She may also lack necessary expertise in circumstances where she does not have time to acquire it.
} 
'control rights') about the assets to an agent. The degree of delegation will vary with the circumstances. It might involve simply giving the agent power to enter into contracts on behalf of the firm. In this case, she delegates the power to make the firm's assets liable to execution by counterparties to relevant contracts entered into by the agent. A more comprehensive delegation might give the agent power to use, buy and sell assets on the firm's behalf. In each case, the aspects of ownership rights which were not delegated to the agent would remain with the entrepreneur, and she alone would retain the right to make these types of control decisions in respect of the assets. This will require a 'sharing agreement': specifying which entitlement in relation to the assets is exercisable by whom, and under what circumstances. In particular, in order to keep in check the economic agency costs of delegating control, the entrepreneur will likely wish to retain an option to terminate the delegation and retake entire control of the asset should the agent underperform, and may wish to include restrictions on the manner in which the agent may exercise the delegated entitlements - such as a requirement that they be exercised for her benefit rather than the agent's own benefit. Here the sharing acts as a mechanism of governance by contraining the agent's freedom to act in a way inconsistent with the entrepreneur's interests: this is either prohibited by the arrangement, or may provoke the entrepreneur to dispossess the agent from control of the assets.

Where it is otherwise efficient for an entrepreneur to own an asset, she may be unable to do so because she is wealth-constrained. The obvious answer is to obtain outside finance. ${ }^{48}$ According to the 'property rights' theory of the firm, financiers use the ability to seize control of the firm's assets as a mechanism of governance. Thus the entrepreneur and the financier can be seen as sharing the entitlements associated with ownership of the organisational assets. This could be done in a variety of ways. If the financier is himself an entrepreneur with appropriate expertise, the assets could be owned jointly (as in a partnership). This too will require a sharing agreement about the circumstances in which the ownership entitlements may be exercised. A simple mechanism would be to require the unanimous consent of each proprietor to exercise ownership rights. However, as the number of participants increases, the costs of information-gathering, communication and negotiation about what to do (collectively, 'the costs of decision-making') rise exponentially. In many cases, a unanimity rule

\footnotetext{
${ }^{48}$ She may also do this to benefit from the advantages of risk-sharing.
} 
would be replaced by other decisional rules, such as majority or qualified majority voting. ${ }^{49}$ These too have costs, and it is not difficult to see that beyond a few coowners, it may make sense to delegate the day-to-day management of the asset to an agent, or one of the co-owners, and to reserve for the co-owners collectively the right to remove (by unanimity, majority vote, or whatever rule is chosen) the agent for unsatisfactory performance..$^{50}$

Alternatively, ownership rights might be shared sequentially (as with a lending agreement). In this case, the entrepreneur retains control unless some verifiable contingency occurs — such as failure to repay an instalment - whereupon the financiers take control. This, again, will require a sharing agreement detailing circumstances under which control will change, and any restrictions on the manner in which the entrepreneur may exercise her entitlements in states of the world in which she has control.

It may be worth considering briefly how such sharing arrangements map onto typical forms of business organisation. The simplest business organisation, namely agency, involves only delegation of entitlements to control assets by the principal to his agent. Those entitlements not so delegated of course remain the principal's. Where two principals combine their firms to form a partnership, this involves joint sharing, between the partners, of the entitlements of ownership in relation to the business assets. Although some entitlements will be exercised jointly-that is, collectively by the partners - most partnerships will combine this with some delegation amongst the partners of responsibility for particular types of control decision. The delegated entitlements will be exercised by the delegate alone, in contrast to those which remain subject to the collective decision-making of the partners.

Now consider debt finance. If an entrepreneur (or a partnership, or indeed a company) borrows money to fund her business, this can be understood as a sequential sharing of entitlements between the creditor and the entrepreneur. That is, the entitlements are exercisable by the entrepreneur so long as she continues to make

\footnotetext{
${ }^{49}$ The goal would be to select a rule that minimises the sum of the costs of decision-making and the costs of the externalities each co-owner has freedom to impose on the others through self-interested choices. See J.M. Buchanan and G. Tullock, The Calculus of Consent (Ann Arbor: University of Michigan Press, 1962), 63-116.

${ }^{50} \mathrm{ibid}$.
} 
repayments. ${ }^{51}$ Where there is more than one creditor, there may be joint sharing of the (contingent) entitlements between the creditors. That is, should the entrepreneur default on her debts generally, then the entitlements become exercisable by the creditors collectively. ${ }^{52}$

A typical public company can be seen as involving a particularly complex sharing arrangement, combining elements of each of the above. There is sequential sharing between shareholders and creditors, and delegation from shareholders to managers. ${ }^{53}$ There will also be joint sharing between shareholders of the aspects of ownership that are not delegated to managers: namely residual returns and the right to remove the delegates. ${ }^{54}$ This combination of sharing arrangements is portrayed in Figure 1.

\section{Figure 1: Typical Entitlement-Sharing Arrangements in a Public Company}

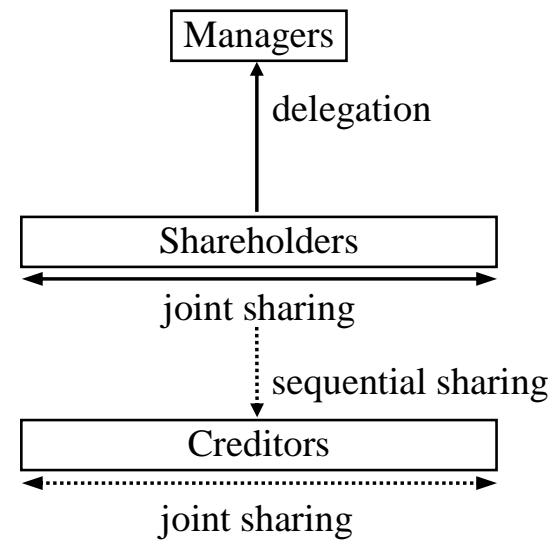

\footnotetext{
${ }^{51}$ Of course this is a generalisation, because the transfer of entitlements to the creditor on default is not complete. It is typically only for the purpose of realising the assets to repay the loan, after which entitlements to any residual value are returned to the debtor.

${ }^{52}$ Alternatively, the entrepreneur may wish to arrange things such that the (contingent) sharing between the creditors is sequential, with a designated order of priority for their respective abilities to exercise entitlements in relation to the assets.

53 'Delegation' is used here (as, more generally is the notion of 'shared ownership') in a functional sense: for the technical position, see below n $\underline{838380}$ and text thereto.

${ }^{54}$ Similarly, if the firm is in default, then shareholders' rights are transferred to creditors, who will exercise them jointly.
} 


\subsection{Shared Control and the Problem of 'Undermining Transactions'}

In the 'property rights' framework, the firm is therefore characterised as a collection of people and assets, with ownership of the latter carefully allocated amongst the former. What then, are the implications for organisational law? At first blush, this seems to imply a simple recharacterisation of the contractarian theory: instead of being a simply nexus of contracts, the firm is now a nexus of contracts about assets. ${ }^{55}$ Whilst it can be argued that the terms of such contracts might differ from the 'pure' contractarian account, ${ }^{56}$ this does not escape from the limitations of the contractarian account.

A purely contractual allocation of control rights will run into difficulties, however.

However, the use of shared control as a governance mechanism is liable to be upset in relation to those parts of the entitlements of ownership which give the owner power to transfer entitlements to third parties. For example, a co-owner may alienate an asset for a consideration that maximises his private utility, but not the utility of the co-owners as a whole. Or an agent may render the assets liable to execution for the non-performance of a contract that does not benefit the co-owners as a whole, simply to secure some personal benefit. What is especially pernicious about agency problems involving alienation and contracting (as opposed simply to 'use-decisions') is that they systematically undermine the other co-owners' ultimate 'threat' of terminating the opportunist's co-ownership. An opportunistic grant of entitlements to a third party can simultaneously reduce the other co-owners' ability to exercise control rights whilst netting the opportunist a private benefit of greater value than the share he might stand to lose.

If one participant in a firm (let us for simplicity refer to him as 'A') appropriates an organisational asset for himself in a manner inconsistent with the agreement about the sharing of entitlements in relation to the assets, then enforcement is a straightforward matter. The rights of the other co-owners (for simplicity, we shall call them ' $\mathrm{P}_{\text {' }}$ ) can be asserted against the agent simply because

\footnotetext{
${ }^{55}$ O. Hart, 'An Economist's Perspective on the Theory of the Firm' (1989) 89 Colum LR 1757, 1771.

${ }^{56}$ See eg, M.M. Blair and L.A. Stout, 'A Team Production Theory of Corporate Law' (1999) 85 Va LR 247.
} 
he has promised not to do this. However, if A has general personal creditors, then a contractual remedy solely against him would offer only limited protection. His personal creditors might become entitled to execute against the asset. If $\mathrm{P}$ did not act quickly, it might be too late.

This conflict between claims of $\mathrm{P}$ and those of third parties ('TPs') is even starker in situations where A has purported to alienate the asset, or to enter into a contract with a third party on the non-performance of which the asset is to be rendered liable to execution. In each case, if P's entitlement may be displaced by those of TPs, then the 'underminig transaction' problems discussed above make the sharing of ownership — and thereby the organisation of firms — considerably more costly.

In such cases, a simple contractual agreement between $\mathrm{A}$ and $\mathrm{P}$ about how entitlements are to be exercised may be insufficient to control the problem of 'undermining transactions'. If this problem is not controlled, then the effectiveness of shared control as a governance mechanism would be greatly reduced. It is here that the law has a distinct function to play by giving effect to the sharing agreements not as simple contracts but as the contours of shared ownership. In turn, this makes the 'threat value' of the control rights as a governance mechanism more effective.

\subsection{Shared Ownership and Property Law}

As the rules by which property is transferred are themselves aspects of the legal system, it is open to lawmakers to provide that the terms of participants' sharing arrangements about the division of control will be privileged over the putative entitlements granted to third parties.

Functionally, we are comparing 'enforcement against $A$ ' and 'enforcement against a general set of TPs'. This invokes a second dimension of the analytic lawyer's conception of 'property', that of the scope of entitlements. This aspect has, however, been entirely overlooked to date in the property rights theory of the firm. Traditional accounts of this categorisation employ the Roman distinction between rights in rem and rights in personam: proprietary and personal rights. The former are (depending on the particular conception) said to inhere in an asset, or to be 'good against the world'. The latter, on the other hand, inhere in or are good against only 
particular persons. Thus, simply to say that the content of P's entitlement in relation to an asset is entirely residual does not make P the 'owner' if the entitlement is only valid against A. For P's entitlements to be capable of being classed as 'proprietary', they must be capable of being asserted against an open-ended set of persons: that is, they must be general in scope.

The distinction between the content of legal relations and their scope comes out most clearly in the analysis of Wesley Hohfeld. ${ }^{57}$ Hohfeld's account of the legal 'elements' — the fundamental building-blocks from which all legal relations may be created - gives a familiar set of analytical tools for examining the content of legal relations. ${ }^{58}$ Honoré's description of the content of 'ownership' can be understood in Hohfeldian terms as the largest 'bundle of entitlements' that it is legally possible for one person to enjoy in relation to a particular asset. ${ }^{59}$

Hohfeld's commitment to a dyadic conception of legal relations meant that he rejected the idea that rights in rem 'inhere in' an asset, or even that they comprise a single relation between the right-holder and an indefinite number of persons. Rather, he conceived of them as being multiple bilateral relations running in parallel between

\footnotetext{
${ }^{57}$ See T.W. Merrill and H.E. Smith, 'The Property/Contract Interface' (2001) 101 Colum. L. Rev. 773, 780-783; J. Armour and M.J. Whincop, 'Shared Property in Partnership and Close Corporations Law' (2001) 26 J Corp L 983

${ }^{58}$ W.N. Hohfeld, Fundamental Legal Conceptions as Applied in Judicial Reasoning (W.W. Cook ed, New Haven: Yale University Press, 1920), 35-64. Hohfeld argued that all legal relationships could be broken down into their constituent 'fundamental legal relations', each conceived in a dyadic sense (ibid 36). In his terminology, ownership contains a package of privileges (liberties), coupled with rights to prevent others from interfering with the exercise of these privileges. Correlatively, non-owners have no-rights to the particular varieties of enjoyment to which the owner is entitled, and duties not to interfere with the owner's exercise thereof. Honorés description of the content of 'ownership' can be understood in Hohfeldian terms as the largest 'bundle of entitlements' that it is legally possible for one person to enjoy in relation to a particular asset.

${ }^{59}$ Penner has cogently argued that property rights in law cannot be understood without reference to their object. In his view, property rights are always thought of in terms of an asset to which the entitled enjoyment relates: J.E. Penner, 'The "Bundle of Rights” Picture of Property' (1996) 43 UCLA LR 711. This view is consistent with the account given in the text, but its acceptance is not a necessary step in the reasoning.
} 
one owner and many non-owners. He termed such relations multital, and contrasted them with relations existing only between two persons, which he termed paucital. ${ }^{60}$ Hohfeld's analytic technology is, for the purposes of functional analysis,superior to the Roman dualism, because it allows for the uncoupling of the contents of the packages of entitlements referred to as 'property rights' from their scope. Many lawyers tend to think of the contents of these packages as fixed by the law-the socalled 'numerus clausus' of permissible interests. Hohfeld's approach allows us to see that there is no necessary analytic link between the fact that entitlements are multital - that is, have the general scope that is characteristic of proprietary rightsand the particular content of those entitlements.. ${ }^{61}$ Hohfeld's terminology has not passed into the general consciousness of lawyers. In the discussion that follows, we therefore for familiarity refer simply to 'personal' and 'proprietary' rights, drawing upon Hohfeld's analysis only where it is necessary to do so. ${ }^{62}$

Economic theorists do not explicitly discuss the scope of proprietary entitlements, or how these are to be distinguished from personal entitlements. Instead, they appear simply to assume that the enjoyment of 'owners' is protected from interference by non-owners. ${ }^{63}$ This would not matter if there were only one person who could be classed as 'owner' of the firm's assets: their residuary entitlement-set (as described by Honoré) could be asserted against all non-owners. However, where ownership is shared, property law also has a role to play in protecting owners against each other.

Understanding the multital nature of scope of property rights allows a meaningful distinction to be drawn between contracts about ownership and genuinely

\footnotetext{
${ }^{60}$ Hohfeld, above n $\underline{585851,72 .}$

${ }^{61}$ As such, it describes more readily the flexibility of Equity's recognition of proprietary rights, for which the contents of the entitlements may be customised by private agreement between co-owners: R. Nolan, 'Property in a Fund' (2004) 120 LQR 108, 132-133.

${ }^{62}$ The account in the text of course skims over many of the subtle issues debated in the analytic legal literature. However, no attempt is made to offer a complete description of 'property rights'. Rather, that term is used only heuristically, to denote a category of rules for which there are important functional differences from rules of contract law.

${ }^{63}$ See eg, G.D. Libecap, Contracting for Property Rights (Cambridge: Cambridge University Press, 1989), 1-28; Hart, above n 333331, 30; Y. Barzel, Economic Analysis of Property Rights, $2^{\text {nd }}$ ed. (Cambridge: Cambridge University Press, 1997), 55-64 (accounts of determinants of contracts about shared ownership, not mentioning distinction between scope of personal and proprietary rights).
} 
shared ownership. The effect of granting 'proprietary' status to a 'second-order' arrangement sharing entitlements of ownership between two parties (such as A and P) is that internal monitoring costs are greatly reduced. If P's entitlements have full proprietary status, then A simply cannot alienate the asset to a TP without P's consent. The only other way to make the arrangements enforceable against third parties would be for the co-owners to make all potential TPs promise that they would not enter into transactions with any of the co-owners in respect of the co-owned assets that would be injurious to the other co-owners' entitlements. This would be prohibitively costly. Thus the law's articulation of the circumstances under which sharing agreements between organisational participants can be given proprietary (or more accurately, 'multital') effect is, in contrast to the provision of default contractual rules, something that might be expected to make a significant difference to outcomes.

\subsection{Minimising the Total Costs of Shared Ownership}

Reducing the monitoring costs of other shared owners does, however, come at the price of imposing costs on TPs. For every 'unauthorised' transaction where P succeed in asserting their entitlements to an asset against a TP, the latter may suffer a reliance loss of an equivalent or greater amount. If the entitlements of $\mathrm{P}$ are completely enforced in every case, then the sum of the costs imposed on TPs may exceed the savings in P's monitoring costs.

The legal system must therefore make a trade-off between maximising the effectiveness of shared control arrangements for organisational participants, and imposing externalities on third parties. ${ }^{64}$ There are also the procedural costs of administering the system. ${ }^{65}$ All other things being equal, it would be desirable for the legal system to seek to minimise the total costs of shared ownership amongst organisational participants. Property and organisational law employ a mix of 'balancing' strategies, which are not mutually exclusive, to effect this fundamental

\footnotetext{
${ }^{64}$ See Merrill and Smith, above n 575755, 790-792, 803-808.

${ }^{65}$ See T.W. Merrill and H.E. Smith, 'Optimal Standardization in the Law of Property: The Numerus Clausus Principle', (2000) 110 Yale LJ 1, 44-45. Furthermore, there may be dynamic inefficiencies arising from fragmentation of property interests. It is easier to divide property rights (a sole owner's prerogative) than to reunify them (requiring the consent of all co-owners, each of who may 'hold up' agreement). These reunification costs may hamper change when a division that was historically useful has over time ceased to be so: see F. Parisi, ‘Entropy in Property' (2002) 50 Am J Comp L 595.
} 
trade-off. Each has comparative (dis)advantages in relation to some elements of the total cost function, and therefore the selection of the optimal mix of strategies will depend upon the context.

One basic strategy is simply to restrict to the types of entitlement-sharing arrangement that may be agreed to a closed list. This is the so-called 'numerus clausus' rule of Civilian legal systems. ${ }^{66}$ In its simplest form, the criterion for enforcement of co-owners' entitlements is whether they fall within the list: provided that they do, they trump third parties, and vice versa. Such a rule seems cheap to administer. However, its effectiveness at reducing JOA costs and externalities depends crucially on the length of the list and the way in which the chosen arrangements are selected. As we have seen, shared ownership is used as a mechanism of governance by participants in firms, ${ }^{67}$ and so co-owners will want as much flexibility as possible in designing structures appropriate for their needs. Third parties will on the other hand prefer a shorter list, so as to minimise their search costs. Commercial actors will rely on a set of customary indicators to help them identify the type of shared ownership (if any) in place. ${ }^{68}$ As the list gets longer, the costs of such identification will probably grow exponentially. Thus the system will work best with a small list that is chosen carefully, so as to be of maximum utility to those seeking to share ownership. ${ }^{6}$ Of course, to do this effectively, lawmakers designing the list must have access to an enormous amount of information-sufficient to be able to identify the relevant constituents and their cost functions.

Another basic strategy may be termed selective enforcement. Simple law-andeconomics analysis suggests that the sum of JOA costs and the externalities created by property law would be minimised by a rule which allocated the risk of loss to the

\footnotetext{
${ }^{66}$ U. Mattei, Basic Principles of Property Law (Westport, CT: Greenwood Press, 2000), 14.

${ }^{67}$ Above, text to nn 3333331-393937.

${ }^{68}$ Provided that the contents of this list are widely known, a restriction of this sort can reduce search costs for third parties, as the sorts of questions that they need ask may be standardised.

${ }^{69}$ B. Rudden, 'Economic Theory v. Property Law: The Numerus Clausus Problem', in J. Eekelaar and J. Bell (eds), Oxford Essays on Jurisprudence, $3^{\text {rd }}$ ed (Oxford: Oxford University Press, 1987), 239, 254-256; Mattei, above n 66 $\underline{6658}$, 39; Merrill and Smith, above n 656562, 38-41.
} 
party who is able to avoid it most cheaply-either $\mathrm{P}$ or $\mathrm{TP} .{ }^{70}$ Of course, it is unlikely to be possible to say a priori which of these parties is likely to be the 'least-cost avoider.' Whilst the costs to P of monitoring A's actions are likely to depend on the nature and structure of the business, the costs to TP of discovering whether or not the transaction is permitted under A's bargain with $\mathrm{P}$ are likely to vary according to the circumstances of the particular transaction. ${ }^{71}$ However, if at the time a claim for enforcement is brought (that is, ex post), a court can compare co-owners' monitoring costs with TP's search costs, then the 'least-cost avoider' principle can be directly applied by giving effect to co-owners' entitlements only if they have the higher costs.

The classic examples of legal rules that can be understood as performing a function of this type are the common law doctrine of apparent authority and the bona fide purchaser rule in equity. ${ }^{72}$ The former holds a principal liable on an unauthorised contract where it reasonably appeared to the third party that the agent in fact had authority to enter into the transaction on the principal's behalf. ${ }^{73}$ The latter allows a party with an equitable interest in an asset to have their claim defeated by a third party who purchases the asset for value from a fiduciary in circumstances under which the third party reasonably believed that the fiduciary was entitled to sell. The rules are functionally equivalent: for the application of either it is necessary to consider the

\footnotetext{
${ }^{70}$ The classic analysis is G. Calabresi, The Costs of Accidents: A Legal and Economic Analysis (New Haven: Yale University Press, 1970). For a demonstration of the generality of Calabresi's approach, see R. Cooter, 'Unity in Tort, Contract and Property: The Model of Precaution' (1985) 73 Calif LR 1.

${ }^{71}$ For example, if A enters into a transaction of modest value that is of a sort typically conducted by agents in his position, but in fact is prohibited under the terms of his agreement with $\mathrm{P}$, it would be very costly for TP to discover this - perhaps even more so than for $\mathrm{P}$ to monitor A to prevent this from happening. Yet if A had instead entered into an irregular, high-value transaction, the costs to TP of determining its status would probably be much lower.
}

72 See A. Schwartz and R.E. Scott, Commercial Transactions: Principles and Policies, 2nd ed. (Westbury, NY: Foundation Press, 1991), 488-494; M.J. Whincop, 'Nexuses of Contracts, The Authority of Corporate Agents, and Doctrinal Indeterminacy: From Formalism to Law and Economics' (1997) 20 UNSW LJ 274, 284-97; D. Fox, 'Constructive Notice and Knowing Receipt: An Economic Analysis' [1998] 57 CLJ 391; Armour and Whincop, above n 575755, ______ Merrill and Smith, above n 575755, 806 (discussing 'protective rules'); B. Medina, 'Augmenting the Value of Ownership by Protecting it Only Partially: The "Market-Overt" Rule Revisited', College of Management Academic Studies Law School Working Paper (2003).

\footnotetext{
${ }^{73}$ Strictly speaking, of course, the doctrine is based upon a 'holding out' by the principal. This can be thought of as an essential precondition for it to be 'reasonable' for the third party to rely.
} 
context of the transaction in question, and whether it was of such a nature as to make it unreasonable for the third party so to rely. ${ }^{74}$

A selective enforcement strategy means that there is no need for the attributes of shared ownership arrangements to be fixed by law. Thus participants are free to structure the terms on which they will share entitlements as best suits their needs: an agent's actual authority to render his principal's assets liable to execution, or a trustee's power to alienate trust assets, are capable of infinite refinement by the terms of the agreement between the agent and principal or trustee and settlor respectively. ${ }^{75}$ However, this flexibility for participants may necessitate greater administration costs than the numerus clausus strategy, for courts must engage in fact-intensive enquiries as to parties' relative knowledge. Yet the back-and-forth interplay between commercial practice and legal standards engendered by tests couched in terms of 'reasonableness' means that the administration costs are probably much lower than they at first appear.

A third strategy is to institutionalise some sort of procedure for disseminating information about sharing arrangements used-for example a central registerthereby lowering search costs. ${ }^{76}$ Many interests in property are registered, and registers often keep information not only about the existence of interests, but also about their contours. ${ }^{77}$ This allows a registration system to maintain flexibility for coowners. The costs of administration and costs for third parties will depend in part on the technology available for dissemination of registered information - the more costly it is to become informed, the greater the externalities.

\footnotetext{
${ }^{74}$ As a matter of law this equivalence is not exact, as was recently pointed out by the House of Lords in Criterion Properties plc v Stratford UK Properties LLC [2004] UKHL 28 at [28]-[31]. For present purposes the key similarity is that both depend on the level of knowledge of the third party and the ease with which they could have discovered the defect.

${ }^{75}$ See J. Langbein, 'The Secret Life of the Trust: The Trust as an Instrument of Commerce' (1997) 107 Yale LJ 165, 183-185; H. Hansmann and U. Mattei, 'The Functions of Trust Law: A Comparative Legal and Economic Analysis' (1998) 73 NYU LR 434, 466-469; Nolan, above n 616154, 111-117.

${ }^{76}$ See D.G. Baird, 'Notice Filing and the Problem of Ostensible Ownership', (1983) 12 J Leg Stud 53; Rudden, above n 696961, 246; Merrill and Smith,above n 575755, 805-806; H. Hansmann and R. Kraakman, 'Property, Contract, and Verification: The Numerus Clausus Problem and the Divisibility of Rights' (2002) 31 J Leg Stud S373.

${ }^{77}$ Typically co-owners are given an incentive to register, by denying enforcement to those who have failed to do so
} 


\subsection{Property and the Theory of the Firm}

To recapitulate: recent developments in the theory of the firm, whilst identifying the significance of allocations of control rights, have failed fully to explain the role played by law in facilitating the sharing or partitioning of control of assets between different participants in a firm. An understanding of the significance of the scope of proprietary rights - their 'in rem' character-points the way to a more complete explanation of the role played by law in supporting business enterprise. In particular, only property law can provide automatic enforcement of arrangements for sharing allocations of entitlement to residual control in relation to assets used in productive enterprise. Moreover, the way in which the costs to third parties are taken into account will have a significant impact on the degree of flexibility enjoyed by participants in the firm to structure their sharing arrangements so as to respond most appropriately to their particular needs. The claim of this section is therefore that a fuller understanding of the functional significance of the role played by legal rules responding to the problem of undermining transactions - that is, the determination of which shared control arrangements can be made to bind third parties, and under which circumstances - can at once enrich the economic theory of the firm and provide the basis for an account of the non-trivial functions of corporate law. ${ }^{78}$

We believe that this analysis has the potential to yield insights for both economists and lawyers. An economist might respond that the distinction between personal and proprietary rights is simply implicit in the notion of 'property rights'. It is not, however. Giving proprietrary effect to the claims of participants in the firm necessarily involves subordinating the claims of third parties who deal with the firm. A trade-off must be made, and there are a range of different ways in which this can be done. The choice may matter for the overall efficiency of organisational law. Thus

\footnotetext{
78 An economist may note the structural similarity between the regulatory character of the various strategies that limit the scope of property rights so as to minimise third party costs, and those rules which deny enforceability to contracts that impose externalities - for example, contracts to pollute or to commit a crime. This seems, however, to be only a point of semantics. Regardless of how the relevant body of rules are described, it is nevertheless the case that (i) their existence has so far been largely overlooked in scholarship on the theory of the firm; and (ii) that they have a role to play that is functionally more significant than the provision of contractual default rules.
} 
'property rights' cannot be assumed to be analytic primitives, but must themselves be unpacked and their contours specified.

A lawyer might equally consider the 'insight' that proprietary rights differ from personal ones to be so obvious as not to be worth stating, and take its articulation in relation to the theory of the firm as further confirmation of the inadequacy of 'law and economics' analysis. Yet all too often, legal analysis of proprietary rights is focused on descriptive rather than functional analysis. A functional account of proprietary rights in relation to organisational law shows that rules which are typically categorised under a range of different headings can and should usefully be analysed together as part of the economically non-trivial foundations of organisational law. These include not only the obvious cases of shared ownership properly so-called (trusts and shared legal ownership) and legal personality, but also agency law and much of debtor-creditor law. To make this point more concrete, we now apply the analytic framework developed in this section to English company law.

\section{The Proprietary Foundations of Corporate Law}

\subsection{A Taxonomy of the Law Relating to Companies}

The property rights theory of the firm argues that the contingent allocation of control rights responds to agency costs between participants in the firm: for example, the shareholders' residual right to remove managers assists in focusing managers' attention on the shareholders' interests. ${ }^{79}$ On this view, the law assists participants in delineating the contents of their entitlement-sharing arrangements - that is, the 'sharing arrangements' about the division of control in relation to the business assets. These arrangements are essentially voluntary agreements between the participants, and the law's role here can be seen as that cast for it by the contractarian theory: to

\footnotetext{
${ }^{79}$ See above, text to nn -----
} 
supply 'standard forms' which participants may employ. However, we have argued that the sharing of control itself is liable to be undermined if the the scope of the parcels of entitlements given to each participant is not made, to use Hohfeld's term, 'multital'. That is, parties' entitlements to control in particular states of the world are protected not just against other participants to the voluntary arrangement, but against third parties generally. The idea is captured (albeit loosely) by saying that the arrangements are given proprietary effect.

To clarify the analysis, we now map the structure of the law applicable to companies in a way that distinguishes those aspects that perform the second role, which we term the 'proprietary foundations', from those that perform the first, which we term the 'contractarian superstructure'. ${ }^{80}$ Our application is limited to the law applicable to companies for reasons of space. However, the analytical framework is more general, and a similar division could also be applied to the law applicable to other organisational forms. At the same time, whilst we look at the law applicable to companies, we do not limit the enquiry to company law, strictly so defined. In functional or comparative terms, such a limitation is unhelpful. What matters for our purposes is rather the body of rules, whether described as 'agency', 'debtor-creditor', 'insolvency' or 'company', that permit the sharing arrangements between participants to companies (organisations) to be made effective as against non-participants in the firm.

The discussion is organised by considering in turn the various dimensions of the control-sharing arrangements in typical companies, as unbundled in the previous section. We begin from the premise that the contractarian rules in each case respond to agency costs - the costs of conflicts of interest - generated between the various categories of participant. ${ }^{81}$ The contribution of our taxonomy is to show how each of

\footnotetext{
${ }^{80}$ The distinguishing criterion is whether the provisions in question could be replicated by private contract. If they could, then (mandatory rules apart) their function is essentially as the 'standard form' described by the contractarian theory. If they could not be replicated by contract because the set of potentially affected parties is indefinitely large, then they are better viewed as property law rules.

${ }^{81}$ The leading functionalist account of corporate law divides these into three basic agency problems or conflicts of interest, namely between (i) shareholders and managers; (ii) shareholders and each other; and (iii) shareholders and creditors (Kraakman et al, above n 6, 21-22). To these might usefully be added a fourth, between (iv) creditors and each other: see D. Skeel, 'Corporate Anatomy Lessons' (2004) 113 Yale LJ 1519, 1550-1559.
} 
these sets of arrangements is in turn supported by other rules that give propretary effect to the control-sharing arrangements. That is, they make them 'stick' as against third parties to counteract the problem of undermining transations. foundations drawn from. Table 2 summarises what follows. The discussion is organised around the various axes of conflict of interest between participants, in order to be able to articulate in relation to each, first the 'sharing arrangements' or contractarian aspects of organisational law, and secondly, the proprietary foundations which support their effectiveness.

Table 2: The 'Proprietary Foundations' of Corporate Law

\begin{tabular}{|c|c|c|c|}
\hline \multirow{2}{*}{ Functional problem } & \multirow{2}{*}{$\begin{array}{c}\text { Entitlement } \\
\text { sharing }\end{array}$} & \multicolumn{2}{|c|}{ Relevant Aspects of Law } \\
\cline { 3 - 4 } & Joint & $\begin{array}{c}\text { Board general managerial power, } \\
\text { law of meetings, class rights, } \\
\text { Unfair prejudice remedy, derivative } \\
\text { action, shareholder agreements }\end{array}$ & $\begin{array}{c}\text { Ostensible authority, Power } \\
\text { of board to bind company, } \\
\text { bona fide purchaser and } \\
\text { notice doctrines; }\end{array}$ \\
\hline $\begin{array}{c}\text { Director-shareholder } \\
\text { conflicts }\end{array}$ & Delegation & $\begin{array}{c}\text { Directors' duties, general meeting's } \\
\text { power to remove directors, } \\
\text { shareholder decision rights }\end{array}$ & $\begin{array}{c}\text { Overreaching, Registration } \\
\text { Shareholder-creditor } \\
\text { conflicts }\end{array}$ \\
\hline $\begin{array}{c}\text { Sreditor-creditor } \\
\text { conflicts }\end{array}$ & Sequential & $\begin{array}{c}\text { Limited liability), share capital, } \\
\text { wrongful trading, loan covenants }\end{array}$ & $\begin{array}{c}\text { Security interests, } \\
\text { fraudulent conveyance law }\end{array}$ \\
\hline Joint & N/A & $\begin{array}{c}\text { Corporate insolvency law, } \\
\text { preference law }\end{array}$ \\
\hline
\end{tabular}

(a) Shareholder-shareholder and director-shareholder conflicts

If there were no board of directors, then the shareholders would be empowered together to exercise the entitlements of ownership in relation to corporate assets. They would share these entitlements jointly - that is, the entitlements could only be exercised through some collective decision-making mechanism. A unanimity rule would be unwieldy because of the costs of making decisions, so instead company law provides a framework within which decisions may be made by majority vote. ${ }^{82}$ Even

\footnotetext{
${ }^{82}$ CA 1985, Part XI, Ch IV (Meetings and Resolutions); Table A, regs 36-63; CA 2006, Part 13
} (Resolutions and Meetings); Draft Model Articles (Private Companies), regs 35-45; (Public 
this, however, may prove too costly for regular use, hence the allocation of jurisdiction to make business decisions to the board of directors. ${ }^{83}$ To encourage the directors to exercise these powers for the benefit of the business, as opposed to their own benefit, there is a complex body of law concerning directors' duties in the performance of their functions. ${ }^{84}$ Moreover, power to make a number of important decisions, sufficiently significant to be worth incurring the costs of shareholder decision-making, is retained by shareholders. This includes of course the appointment and removal of the board. ${ }^{85}$ Where the shareholders make decisions, there is potential for majorities to seek to expropriate minority claimants. Company law seeks to protect the interests of minorities through a range of mechanisms, most significantly the imposition of restrictions on the alterations of the constitution, ${ }^{86}$ and the provision

Companies), regs 27-41. If unanimous shareholder consent can be obtained, these formalities may be waived: Re Duomatic Ltd [1969] 2 Ch 365; Wright v Atlas Wright (Europe) Ltd [1999] 2 BCLC 301.

${ }^{83}$ Table A, reg 70; Draft Model Articles (Private Companies) reg 2; (Public Companies) reg 2. This is understood as an exclusive grant of management power to the board: Automatic Self-Cleansing Filter Syndicate Co Ltd v Cunninghame [1906] 2 Ch 34. However, it is open to modification by the shareholders (see Cane v Jones [1980] 1 WLR 1450) and indeed is frequently waived in smaller companies where unanimous shareholder consent is relied upon for decision-making.

${ }^{84}$ CA 2006, ss 170-177. These include duties (i) to act within their powers; (ii) to promose the success of the company (iii) to exercise independent judgment; (iv) to exercise reasonable skill, care and diligence; (v) to avoid conflicts between self-interest and duty; (vi) not to accept benefits from third parties and (vii) to declare any interest in a proposed transaction or arrangement. See generally P.L. Davies, Gower's Principles of Modern Company Law (London: Sweet \& Maxwell, $7^{\text {th }}$ ed, 2003), Ch 16.

85 CA 1985, s 303; Table A, regs 73-81; CA 2006, ss 168-169; Draft Model Articles (Private Companies) regs 16-17; (Public Companies) regs 19-21. It also includes alterations to the constitution (CA 1985 ss 4, 9, 121; CA 2006 ss 21-22, 28), authorisation of: certain transactions with directors and their associates (CA 1985 ss 320, 322A, CA 2006 ss 41, 190), issues of shares (CA 1985 s 80; CA 2006 ss 549-551), waiver of pre-emption rights (CA 1985 ss 91, 95; CA 2006 ss 567-573), repurchases of shares (CA 1985 ss 164-166; CA 2006 ss 690-692), distributions (Table A, reg 102; Draft Model Articles (Public Companies) reg 70), reductions of capital (CA 1985 s 135; CA 2006 s 641), financial assistance (where permissible: CA 1985 ss 155-158; $c f$ CA 2006 ss 677-683) and decisions to wind up the company (Insolvency Act 1986 ss 84(1), 122(1)(a)).

${ }^{86}$ Both through 'default' rules encompassed in the Allen v Gold Reefs of West Africa Ltd [1900] 1 Ch 656 line of case law, and the facility to specify more powerful protection through the use of class rights (see CA 1985 ss 17, 125-129; CA 2006 ss 22, 629-640). 
of remedies to minority shareholders for particularly serious harm caused by majority misbehaviour. ${ }^{87}$

Each of these aspects of the legal framework affects only participants internal to the corporate enterprise and are largely susceptible to modification by these parties. ${ }^{88}$ Even those areas that may not be modified, such as directors' duties, ${ }^{89}$ can be thought of as 'contractarian' in the sense that had this body of law not existed, such rules could be replicated (or created) by private contracts between participants. ${ }^{90}$ Thus these rules may be viewed as part of the 'contractarian superstructure' of corporate law.

Nevertheless, the laws performs an important additional role in supporting the enforcement of these 'contractual' arrangements against third parties. This comes into play in situations where one of the parties - a director or shareholder - acts without authority under the constitution or in breach of their duties (where applicable), in a transaction involving a third party. That is, there is an attempted alienation or grant of entitlements in respect of corporate assets that is contrary to the parties' internal arrangement about how these entitlements are to be shared. This would encompass not only attempts to sell the assets, but also attempts to use the assets to bond unauthorised contracts, ${ }^{91}$ or attempts to allow newcomers to participate in the sharing of control of the assets - that is, unauthorised issues or transfers of shares, or putative

\footnotetext{
${ }^{87}$ Namely, the derivative action (See Prudential Assurance v Newman Industries (No 2) [1982] Ch 204, 210-225; CA 2006 ss 260-264) and the statutory remedy for unfair prejudice to the petitioner's interests (CA 1985 s 459; CA 2006 s 994).

88 '[T] he manner in which the affairs of the company may be conducted is closely regulated by rules to which the shareholders have agreed.' (Per Lord Hoffmann, O'Neill v Phillips [1999] 1 WLR 1092, 1098).

${ }^{89}$ CA 1985 s 310; CA 2006 s 232.

${ }^{90}$ It seems perfectly plausible that such duties and a corresponding liability to account could be created bilaterally by contract. It is probable that a court would grant 'disgorgement measure' damages if the contract expressly provided for this remedy (see Att-Gen v Blake [2001] 1 AC 268, 287, 291-292). Difficulty in pre-estimating loss would militate against characterising such a term as a penalty (see Dunlop Pneumatic Tyre Ltd v New Garage and Motor Co Ltd [1915] AC 79, 87-88, 96). In any event, the obligation to account could be framed as an alternative primary obligation, rather than a secondary obligation (see Lombard North Central Finance plc v Butterworth [1987] 2 WLR 7, 16-17).

${ }^{91}$ That is, to enter into contracts on the company's behalf: in this case it is the corporate assets to which the counterparty will look for satisfaction if performance is not forthcoming.
} 
appointment of directors. Formerly it also included, by virtue of the doctrine of ultra vires, purported transactions that exceeded the company's objects clause. ${ }^{92}$

In each of the foregoing situations, an unauthorised transaction may be set aside against a third party. To provide for this result by contracts with all potential third parties would be prohibitively costly. The open-ended set of potentially affected parties gives away the proprietary nature of the rules in question. In corporate lawyers' terms, the crucial rules are those of agency and trusts law. Thus unauthorised attempts to alienate corporate assets,${ }^{93}$ or to create contractual claims to corporate assets, or the performance of which is bonded by corporate asssets (that is, which would render corporate assets liable to execution in the case of non-performance), ${ }^{94}$ or to entitle newcomers to become shareholders ${ }^{95}$ or directors, ${ }^{96}$ may not bind the corporate assets or the existing parties to the corporate 'bargain'. ${ }^{97}$ Similarly, transactions in which directors breach their fiduciary duties may give rise to proprietary claims against directors and third parties by the company, ${ }^{98}$ the law drawing an analogy with transactions by a trustee in breach of trust. ${ }^{99}$

92 Ashbury Railway Carriage and Iron Co Ltd $v$ Riche (1875) LR 7 HL 653; The doctrine was abolished as regards third parties by the implementation of the First EC Company Law Directive (68/151/EEC [1968] OJ 65/8; CA 1985 ss 35-35B; CA 2006 ss 39-40).

${ }^{93}$ Rolled Steel, ibid 297-298.

${ }^{94}$ Criterion Properties v Stratford, above n 747466 at [29]-[31].

${ }^{95}$ Bank of Hindustan, China and Japan Ltd v Alison (1871) LR 6 CP 222, 226-227 (issue in excess of authorised capital); Re A Company (No 005134 of 1986), ex parte Harries [1989] BCLC 383, 396 (issue in contravention of pre-emption rights); Re London and New York Investment Corpn [1895] $2 \mathrm{Ch}$ 860, 869; EIC Services v European Internet Capital Ltd [2004] EWCA Civ 1069 at [19]-[41] (issue in excess of directors' authority); Tett v Phoenix Property and Investment Co Ltd [1986] BCLC 149, 162, 167 (unauthorised share transfer).

${ }^{96}$ Boschoek Pty Co Ltd v Fuke [1906] 1 Ch 148, 163; Morris v Kanssen [1946] AC 459, 471-473.

${ }^{97}$ In many cases, of course, whether this is so will depend on the third party's level of knowledgereflecting the balancing function performed by property law rules. See below, text to nn 130-134.

${ }^{98}$ Russell v Wakefield Waterworks Co (1875) LR 20 Eq 474, 479; Belmont Finance Corp v Williams Furniture Ltd (No 2) [1980] 1 All ER 393, 405 (dispositions); Howard Smith Ltd v Ampol Petroleum Ltd [1974] AC 821, 838 (issue of shares); CA 2006 s 178. See also CA 1985 ss 322, 322A, 341; CA 2006 ss 41, 195, 213.

${ }^{99}$ Russell v Wakefield Waterworks, above n 989895, 479; Re Lands Allotment Co [1894] 1 Ch 616, 631, 638; Belmont Finance v Williams Furniture (No 2), above n 989895, 405. See generally L.S. Sealy, 'The Director As Trustee’ [1967] CLJ 83. 
Hansmann and Kraakman have prominently called attention to the significance of certain aspects of these proprietary foundations, which they term 'affirmative asset partitioning'. ${ }^{100}$ In essence, their label captures the notion that shareholders are unable to deal with corporate assets in an individual capacity. In particular, shareholders' personal creditors may not execute against corporate assets, but rather are entitled only to the bundle of rights that comprise the shares held in the company. In our view, this is just one aspect of a more general function performed by the law in relation to companies: namely, the giving of proprietary ('multital') effect to restrictions on unauthorised dealings by those sharing the entitlements of ownership of assets. In particular, for affirmative asset partitioning to work, it is necessary first to have rules determining which contracts are 'personal' and which are 'corporate': this function is performed largely by the rules of agency, as applied to organisations.

(b) Shareholder-creditor and creditor-creditor conflicts.

The third source of potential conflict between participants in corporate enterprise is that between shareholders (or shareholders and managers together) and creditors. A basic feature of any lending arrangement is the contingent allocation of entitlements to control assets between the borrower and the lender. ${ }^{101}$ This is true too of corporate borrowing arrangements. Should the company default on its debts, its creditors become entitled to control its assets. The principle of limited liability means, however, that it is only corporate assets that are so subject, and not the personal assets of shareholders or directors. ${ }^{102}$ This limitation means that shareholders and directors may be tempted, particularly when the company is heading for insolvency, to strip

\footnotetext{
100 Above n Error! Bookmark not defined.Error! Beokmark not defined.10, 394-95. Hansmann and Kraakman argue that 'affirmative asset partitioning' is the only essential role played by organisational law. The rules we have just considered clearly perform the function of preventing shareholders from alienating, or issuing claims against, corporate assets. However, they do much more. Hansmann and Kraakman are right that affirmative asset partitioning is important, but incorrect to claim that it is the only important function.

${ }^{101}$ See above n Error! Bookmark not defined.Error! Bookmark not defined.72.

${ }^{102}$ CA 1985 s 1(2)(a); CA 2006 s 3; Insolvency Act 1986 (henceforth 'IA 1986') s 74(2)(d).
} 
assets, take high-risk gambles, or to increase indebtedness. ${ }^{103}$ Such transactions, where effective, enable the shareholders to expropriate creditors. The law's response to these problems involves a number of rules that restrict transactions that are likely to profit shareholders and/or directors at creditors' expense. Best known of these are the regulation of share capital, ${ }^{104}$ the prohibition on 'wrongful trading', ${ }^{105}$ and the equation on insolvency of the 'interests of the company', which the directors are dutybound to further, with the interests of creditors. ${ }^{106}$

However, both limited liability itself and the aforementioned restrictions on its abuse are best analysed as part of the 'contractual superstructure'. It would be possible in each case to replicate them by contract. ${ }^{107}$ Thus those contracting with outsiders on behalf of the company could insert a standard clause to limit liability, as appears to have been done by insurance firms formed prior to the Limited Liability Act $1855 .{ }^{108}$ Moreover, these contracts could also contain provisions whereby corporators promise not to engage in activities that will harm creditors, and agree to face personal liability should they do so: loan covenants and personal guarantees.

The proprietary foundations in relation to creditors are found in the law of secured credit and insolvency. ${ }^{109}$ Secured credit allows a debtor to promise its

\footnotetext{
${ }^{103}$ Jensen and Meckling, above n 181817, 333-343; A. Schwartz, ‘A Theory of Loan Priorities,' (1989) 18 J Leg Stud 209, 228-234.

${ }^{104}$ CA 1985 Parts V and VIII, restricting gratuitous transfers of corporate assets to shareholders. See J
} Armour, 'Share Capital and Creditor Protection: Efficient Rules for a Modern Company Law?' (2000) 63 MLR 355, 363-370.

105 IA 1986 s 214. See R. Mokal, 'An Agency Cost Analysis of the Wrongful Trading Provisions' [2000] 59 CLJ 335.

${ }^{106}$ Kinsela v Russell Kinsela Pty Ltd (1986) 4 NSWLR 722, 730; West Mercia Safetywear Ltd v Dodd (1989) 4 BCC 30, 33; Official Receiver v Stern [2001] EWCA Civ 1787 at [32], [2002] 1 BCLC 119, 129-130. See R. Grantham, 'The Judicial Extension of Directors’ Duties to Creditors' [1991] JBL 1.

107 The only exception is the limited liability of shareholders from tort claims against the enterprise.

108 See Hallett v Dowdall (1852) 21 LJQB 98, 118 ER 1; Re Merchant Traders' Ship, Land and Insurance Association (1852) 5 De G \& Sm 386, 393-394, 64 ER 1165, 1168; Re European Assurance and Insurance Association (1875) 1 Ch D 307, 322-333 ('limited liability' clause inserted into joint stock company's contracts with creditors effective); cf Re Sea, Fire \& Life Insurance Co (1854) 3 De G M \& G 459, 43 ER 180; Re Norwich Equitable Fire Assurance Co (1887) 27 Ch D 515 (clause inserted simply into deed of association ineffective).

109 The doctrine of ultra vires also served a similar function in an earlier era. By restricting the ability of shareholders and directors to alter the direction of the company's business, it reassured creditors that 
creditor, with proprietary effect - that is, enforceable against third parties-(i) a certain priority ranking and (ii) that certain assets will not be alienated without its consent. Thus, a security interest prevents the debtor from alienating collateral without the secured creditor's consent, ${ }^{110}$ and, through the creditor's priority in insolvency, ensures that subsequent borrowings will not dilute its claim. ${ }^{111}$ Furthermore, this is done in a way that is 'self-enforcing', for it automatically binds outsiders. ${ }^{112}$

A more general restriction is supplied by what was formerly known as 'fraudulent conveyance' law, now termed 'transactions at an undervalue'. ${ }^{113}$ This allows creditors to challenge eve-of-insolvency transactions that harm their interests, setting them aside against third parties generally. Whilst a prohibition on transactions at an undervalue may be understood as a term that any creditor would want written into a contract with their debtor, ${ }^{114}$ its enforcement against third parties generally is not something that a contractual prohibition would be capable of achieving. ${ }^{115}$ The law of transactions at an undervalue can therefore be understood as part of the proprietary foundation of the law applicable to companies. ${ }^{116}$

Finally, there are costs arising from conflicts between creditors. For most companies, these are potential rather than actual costs, because their impact is only

the riskiness of their investment would not change. See Ashbury v Riche, above n 929289, 667; Cheffins, above n 1, 527-528.

110 C.W. Smith and J.B. Warner, 'Bankruptcy, Secured Debt and Optimal Capital Structure: A Comment' (1979) 34 J Fin 247.

${ }^{111}$ Schwartz, above n 103, 228-234.

112 A. Schwartz, 'Priority Contracts and Priority in Bankruptcy' (1997) 82 Cornell LR 1396, 1412 1414.

${ }^{113}$ IA 1986 ss 238, 423.

114 D.G. Baird and T.H. Jackson, 'Fraudulent Conveyance Law and its Proper Domain' (1985) 38 Vand LR 829, 835-836.

115 Note, 'Fraudulent Conveyance Law as a Property Right' (1987) 9 Cardozo LR 843, 847-849; J.B. Heaton, 'Incomplete Financial Contracts and Non-Contractual Legal Rules: The Case of Debt Capacity and Fraudulent Conveyance Law' (2000) 9 Journal of Financial Intermediation 169.

116 This is not because the source of this cause of action is in 'property law'-its source is indeed statutory. Rather, our grouping it as part of the 'proprietary foundations' is based on the function of this rule as a means of giving effect, as against third parties, to basic terms of the control-sharing arrangements between (corporate) debtors and their creditors. 
felt when the company becomes insolvent. However, where this does happen, very significant costs can arise from the attempts of multiple creditors to exercise their entitlements simultaneously. ${ }^{117}$ At this point, corporate insolvency law steps in to effect a collective transformation of creditors' rights. ${ }^{118}$ Once again, attempts to deal with the assets in ways that are inconsistent with these orderings will bind third parties. ${ }^{119}$ English law provides for different insolvency procedures to be invoked depending on the entity that is insolvent. ${ }^{120}$

\subsection{Relevant 'Balancing'Strategies}

The foregoing taxonomy allows us to identify the rules that form the 'proprietary foundations' that underpin corporate enterprise by making the control-sharing arrangements between participants in the firm 'stick' as against third parties. These can now be usefully analysed by considering the various strategies they employ for maximising the effectiveness of shared control arrangements for organisational participants, and minimising the enforcement externalities. A version of the simplest and most restrictive strategy, numerus clausus, can be seen in operation at the level of organisational form. Only a limited number of forms of business organisation are available, each of which has certain immediately recognisable and distinctive features that relate to the way in which the entitlements of ownership are shared. The registered company (whether limited by shares, guarantee, or unlimited) is just one of these- the others comprising agency, trusts, partnerships, Limited Partnerships and

117 T.H. Jackson, 'Bankruptcy, Non-Bankruptcy Entitlements, and the Creditors' Bargain' (1982) 91 Yale LJ 857, 859-868; M.J. Roe, 'The Voting Prohibition in Bond Workouts' (1987) 97 Yale LJ 232, 236-239.

${ }^{118}$ IA 1986 ss 128, 130, Sch B1, paras 42-44; Ayerst v C \& K Construction Ltd [1976] 167, 176-180; Re Aro Co Ltd [1980] Ch 196, 204-205; Bristol Airport plc v Powdrill [1990] Ch 744, 758; Wight v Eckhardt Marine GmbH [2003] UKPC 37 at [27], [2004] 1 AC 147, 155-156.

${ }^{119}$ See eg IA 1986 s 127.

${ }^{120}$ IA 1986, Parts VIII and IX (Individual Voluntary Arrangement and Bankruptcy procedures for sole proprietorships); IA 1986, Parts I-VII and Sch B1 (Company Voluntary Arrangement, Administration, Receivership and Liquidation procedures for companies); Insolvent Partnerships Order 1994, SI 1994/2421 (applying amended provisions of IA 1986 to partnerships and Limited Partnerships); Limited Liability Partnerships Regulations 2001, SI 2001/1090, reg 5 (applying provisions of IA 1986 to Limited Liability Partnerships). 
Limited Liability Partnerships. ${ }^{121}$ Similarly, the law of security interests is said to employ a numerus clausus of property law structures. ${ }^{122}$ The idea in each case seems to be that by limiting the size of the menu, an outer bound may be placed on the costs incurred by third parties in determining the likely allocations of entitlements. ${ }^{123}$ However, the numerus clausus technique is only employed in a very loose sense in relation to organisational form, because participants retain a free hand to customise the terms of the entitlement sharing to organisational assets between themselves. ${ }^{124}$ Moreover, the law also permits parties to customise the terms of non-possessory security interests, ${ }^{125}$ as well as facilitating the use of other devices that function as security even if they are not formally so classified. ${ }^{126}$ This flexibility is facilitated by the complementary use of the two other techniques of property law for resolving the essential trade-off.

The registration strategy is used heavily in company law, with varying degrees of success. In particular, the company's constitutional documents, business address, and the names of its members and directors must all be registered. ${ }^{127}$ The memorandum and articles of association specify the outer boundaries of any corporate agent's powers (the company's objects), the division of these powers between different groups of agents and the procedures for decision-making about how these

\footnotetext{
${ }^{121}$ It is, of course, possible that the menu could be longer. For example, a wider range of organisational forms is offered to business participants in many US jurisdictions. See L. Ribstein, 'The New Choice of Entity for Entrepreneurs' (1997) 26 Capital ULR 325.

${ }^{122}$ R.M. Goode, Legal Problems of Credit and Security (London: Sweet \& Maxwell, $3^{\text {rd }}$ ed, 2003), 31 38 (forms of consensual security limited to pledge, lien, charge and mortgage).

${ }^{123}$ Armour and Whincop, above $n_{\ldots}, 999-1000$.

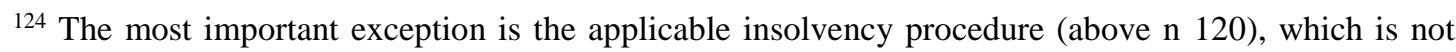
capable of being customised. Until recently, companies and lenders had limited flexibility over insolvency. They could opt, through the grant of a floating charge, to have insolvency dealt with by administrative receivership. This option has been removed by the Enterprise Act 2002 (s 250).
}

${ }^{125}$ See Nolan, above n $\underline{61} \underline{6154}, 117-130$.

${ }^{126}$ Namely title retention and Quistclose trusts. See M.G. Bridge, 'Form, Substance and Innovation in Personal Property Security Law' [1992] JBL 1; M.G. Bridge, 'The Quistclose Trust in a World of Secured Transactions' (1992) 12 OJLS 333.

${ }^{127}$ CA 1985 ss 10, 18; CA 2006 s 9 (memorandum and articles), CA 1985 s 28; CA 2006 ss 78-81 (changes of name), CA 1985 s 288; CA 2006 s 162 (directors), CA 1985 s 352; CA 2006 s 113 (members), CA 1985 s 380 CA 2006 ss 29-30 ('constitutional' decisions). 
powers are to be exercised. Through registration, these documents are available to be consulted by third parties. A related requirement is that the company's name must end in 'Ltd' or 'plc' and must be used in all correspondence, in order to inform third parties that they are dealing with a company rather than an individual. ${ }^{128}$ Similarly, the register of charges gives details of most non-possessory security interests granted by the company. ${ }^{129}$

The registration strategy is complemented in company law by the use of selective enforcement. Where a third party is dealing with an individual agent, the scope of whose power is not set out in the company's constitution, then the counterparty may nevertheless enforce the contract if the agent had apparent authority to enter into the transaction. ${ }^{130}$ In most cases, this enquiry will boil down to the nature of the role that the agent is held out as performing (his 'usual' authority) and the circumstances of the transaction. The more unlikely it would reasonably appear to a third party that an agent of this sort would have authority for a transaction of this sort, the less likely the third party is to succeed. Similar rules govern transactions with third parties that are entered into by directors in breach of their fiduciary duties. These may leave the outsider liable either to have an executory contract set aside or to a proprietary claim by the organization for restitution of its property, unless the counterparty is in good faith and gives value. ${ }^{131}$ The essence of both tests involves a determination of which party could have avoided the transaction at lowest cost. ${ }^{132}$ The same strategy can also be seen at work in relation to fraudulent conveyances. Although the current legislation contains no defence of bona fide purchaser, it does have a substantive requirement that the transaction be effected at an undervalue. ${ }^{133}$

\footnotetext{
${ }^{128}$ CA 1985 ss 25, 348, 349; CA 2006 ss 58-59, 82-83.

${ }^{129}$ CA 1985 Part XII; CA 2006 Part 25.

${ }^{130}$ Freeman \& Lockyer v Buckhurst Park Properties (Mangal) Ltd [1964] 1 QB 480, 503-506.

${ }^{131}$ Rolled Steel, above n 929289, 295-298, 307 (dispositions); Heinl v Jyske Bank, above n 989895, 520-521 (contracts).

${ }^{132}$ See above, text to $\mathrm{nn} 727264-747466$. On the purchaser's side, the more unusual the facts - the more they suggest the vendor is seeking to sell more than she is able - the greater the efforts the purchaser must make to establish that this is not the case: Law of Property Act 1925 s 199, esp. ss (1)(ii)(a). If, given the appropriate level of care, the purchaser still is unaware of the co-owner's rights, then she may buy the assets free of them.
}

${ }^{133}$ IA 1986 ss $238,240$. 
This is precisely the sort of circumstance that would put a third party 'on notice' under the old law and so in functional terms can be viewed as working in a similar manner. ${ }^{134}$

Particularly interesting is the complex interplay in company law between registration and selective enforcement. Early judicial responses to registration seem to have proceeded on the assumption that the register could be consulted easily. Thus the doctrine of 'constructive notice', articulated most clearly by the House of Lords in Ernest $v$ Nicholls, ${ }^{135}$ provides that third parties are deemed to be aware of the contents of all public documents available for consultation at Companies House. Similarly, short shrift was shown to unsecured creditors in Salomon $v$ Salomon, who because of the use of the 'Ltd' suffix, knew that they were dealing with a company rather than an individual. ${ }^{136}$ Unfortunately, it soon became clear that consulting the Register was in most cases prohibitively costly, and so the doctrine of constructive notice could not be employed indiscriminately. ${ }^{137}$

Thus there developed a judicial gloss on the registration strategy. The 'indoor management rule' provides that where there is a procedural restriction in the constitution - that is a transaction requires some authorisation under the company's constitution - an outsider, even if they know of the existence of the procedural hurdle, is entitled to assume that all necessary steps have been taken provided that nothing in the register indicates otherwise. ${ }^{138}$ This is a remarkable piece of judicial casuistry. Taken at face value, the outsider is first deemed to know the entire contents of the public register, but then relieved from making enquiries about whether relevant steps

\footnotetext{
134 J. Armour, 'Transactions at an Undervalue' in J. Armour and H.N. Bennett (eds), Vulnerable Transactions in Corporate Insolvency (Oxford: Hart Publishing, 2003), 37, 40, 46-47.

135 (1857) 6 HL Cas 401.

136 As Lord Macnaghten put it, '[t]he unsecured creditors ... may be entitled to sympathy, but they have only themselves to blame for their misfortunes. They ... had full notice that they were no longer dealing with an individual, and they must be taken to have been cognisant of the memorandum and of the articles of association.' ([1897] AC 22, 53).

137 This was most pronounced in relation to the doctrine of ultra vires. The judiciary were well aware of the way in which an absolute enforcement of restrictions in the objects clause could impose disproportionate costs on third parties. As Lord Parker explained: 'The narrower the objects expressed in the memorandum the less is the subscribers' risk, but the wider such objects the greater is the security of those who transact business with the company.' (Cotman v Brougham [1918] AC 514, 520).

${ }^{138}$ Royal British Bank v Turquand (1856) 6 E\&B 327; 119 ER 886.
} 
have been taken provided that they would in the ordinary course of things have been done. The net result is that the outsider is given incentives to make enquiries to a standard that is remarkably similar to that employed under the 'pure' selective enforcement strategy-namely, whether it was reasonable in all the circumstances for him to rely on the appearance of the transaction's authenticity. ${ }^{139}$

The balance was shifted even further in favour of third parties by the First Company Law Directive, ${ }^{140}$ implemented comprehensively by the Companies Act 1989. This abolished the effects of the doctrine of ultra vires for third parties, and in relation to agency, created a 'safe harbour' for third parties where a transaction is authorised by the board. ${ }^{141}$ Yet even this is not entirely free of selective enforcement. Section 35A of the Companies Act 1985 (section 40 of the Companies Act 2006) is limited in its protection to third parties 'in good faith', although it is for the company to show the absence of this state of mind, and it requires more than what would suffice to show that a third party is 'on notice' at common law. ${ }^{142}$ Perhaps more significantly, the question of what constitutes 'the board' is left in section 35A to general company law-with the result that a selective enforcement approach also seems to be in the process of development in relation to this question. ${ }^{143}$

Similarly, in the realm of secured credit, the interplay of registration and selective enforcement has led to a complex body of law. The registration strategy,

\footnotetext{
${ }^{139}$ Suspicious circumstances relating to a transaction may put a counterparty 'on notice' such that he is unable to rely on the indoor management rule: AL Underwood Ltd $v$ Bank of Liverpool [1924] $1 \mathrm{~KB}$ 775, 788-789; B Ligget (Liverpool) Ltd v Barclays Bank Ltd [1928] 1 KB 48, 56-57; Morris v Kanssen [1946] AC 459, 475; Northside Developments Pty Ltd v Registrar-General (1990) 170 CLR 146, 155, $192,207$.

${ }^{140}$ Above n 929289.

${ }^{141}$ CA 1985 ss 35A; CA 2006 s 40 A second, less celebrated, 'safe harbour' is for transactions effected by a deed signed by two directors: CA 1985 s 36A(4). This will be reduced to a single director whose signature is attested by a witness under the CA 2006 (s 44(2)(b)).

142 First, good faith is presumed in favour of the third party (CA 1985 s 35A(2)(c); CA 2006 s 40(2)(b)(ii)). Secondly, knowledge alone that the transaction exceeds the power of the board will not be sufficient to put the third party in 'bad faith' (CA 1985 s 35A(2)(b); CA 2006 s 40(2)(b)(iii)).

${ }^{143}$ Smith v Henniker Major [2003] EWCA Civ 762, [2003] Ch 182. It appears that an 'apparent board' will suffice (ibid at [108], 213). CA 2006 s 40 refers simply to 'the directors', although there is no indication in the Explanatory Notes to the Act that this change in wording was intended to change the provision's operation (Companies Act 2006 Explanatory Notes, 18). It seems likely that similar difficulties will emerge over the question of when 'the directors' (plural) may be said to have acted.
} 
fully introduced in relation to charges after the courts had had fifty years of experience in relation to companies' constitutional documents, ${ }^{144}$ has always been applied with sensitivity to its impact upon third party search costs. Thus registration of a charge acts as notice of its existence, but not of its contents. ${ }^{145}$ Although on one view, the numerus clausus principle applies not only to the types of security interest that may be created, but also to their attributes, ${ }^{146}$ the better view is that 'customisation' of equitable security interests is perfectly possible, ${ }^{147}$ and that negative pledges and automatic crystallisation clauses take effect subject to selective enforcement - that is, they are only enforceable against third parties with notice of their existence. $^{148}$

\subsection{Evaluating the Mix of Strategies}

As we have seen, the primary contribution of property law to the functioning of corporate law has historically been through the mechanism of selective enforcement. Generally speaking, it is preferable to the numerus clausus strategy because of the greater flexibility it provides for insiders in structuring their sharing arrangements. This is borne out by its comprehensive use in corporate law. The effectiveness of the registration strategy depends largely upon the technology employed for disseminating

\footnotetext{
${ }^{144}$ Companies Act 1900. Section 43 of the Companies Act 1862 had introduced a requirement that companies keep a register of charges at their place of business, but it seems this provision was not really intended to be a means of lowering search costs, for only existing creditors or members were entitled to look at the register-potential creditors had no such right: see Wright v Horton (1887) 12 App Cas 371, 376. Moreover, non-registration did not affect the validity of the charge: ibid.

${ }^{145}$ In particular, not of any unusual circumstances under which a floating charge will crystallise, or the existence of negative pledges: English and Scottish Mercantile Investment Co v Brunton [1892] 2 QB 700, 707; Wilson v Kelland [1910] 2 Ch 306, 313. The precise scope of the doctrine's operation is contentious: see J. de Lacy, 'Constructive Notice and Company Charge Registration' [2001] Conv 122.

146 In particular, that there are certain 'essential' features of a floating charge that may not be customised by contract: see Evans v Rival Granite Quarries Ltd [1910] 2 KB 979, 993-996 (events of crystallisation); Griffiths v Yorkshire Bank plc [1994] 1 WLR 1497, 1535 (negative pledges). See also National Westminster Bank plc v Spectrum Plus Ltd [2004] EWCA Civ 670 at [25]-[31].

${ }^{147}$ Re Brightlife Ltd [1987] Ch 200, 214-215; Fire Nymph Products Ltd v Heating Centre Pty Ltd (1992) 7 ACSR 365 (events of crystallisation); Re Portbase Clothing [1993] Ch 388, 401 (negative pledges).

148 Goode, above n 122, 81-82, 146-148, 181-182 (distinguishing chargee's actual and apparent authority to deal).
} 
registered particulars to outsiders. Where it is cheap for outsiders to become informed, registration is capable of acting as a superior alternative to selective enforcement. However, where this is not the case, it simply acts as a complement, providing a straightforward mechanism for conveying certain types of information and channelling the 'due diligence' questions that third parties are encouraged to make.

Over time, the technology available to insiders seeking to monitor the actions of their delegates has become more effective, with the result that a shift can be discerned in favour of protecting third parties, most noticeably in the realm of corporate contracts. Yet the advent of the Internet means that the costs of consulting the Register have been dramatically reduced for most third parties. ${ }^{149}$ It seems likely that the overall costs of the system would perhaps be reduced by a corresponding shift to allocate greater responsibility to third parties. ${ }^{150}$

\subsection{Two Analytic Payoffs}

Before turning to normative considerations, it is worth examining two ways in which the foregoing argument has implications for the way in which we analyse corporate law.

(a) The (Very Limited) Role of Corporate Personality

A reader who has been following the analysis will have noted that the discussion makes only passing reference to corporate personality. Indeed, the 'building blocks' of property law upon which corporate law is based would allow a structure that arranges shared entitlements to physical assets in a way very similar to that which occurs in companies, but without using the corporate form. ${ }^{151}$ What difference, then,

\footnotetext{
149 The list of information available from Companies House over the Internet, with accompanying prices, can be seen at <http://www.companieshouse.gov.uk/toolsToHelp/productPriceList.shtml $>$.

${ }^{150}$ Arguably such a shift could have been precipitated in relation to security interests had the Law Commission's proposal to change to a 'notice-filing' system, under which filing and searching of the register would be done electronically, been taken up: see Law Commission Consultation Paper 176, Company Security Interests (London: TSO, 2004), 18-20. See now CA 2006, Part 25.

${ }^{151}$ See J. Getzler and M. Macnair, 'The Firm as an Entity Before the Companies Acts' in P. Brand, K. Costello and W.N. Osborough, Adventures in the Law: Proceedings of the British Legal History Conference Dublin 2003 (2004).
} 
does corporate personality make? To the functional analysis of control rights, the answer is 'very little'.

Start with a simple case. If ABCo Ltd is sole owner of its assets, has no outstanding debt and $\mathrm{X}$ (an individual) is the sole owner of the shares in $\mathrm{ABCo}$, then what difference exists between the control that $\mathrm{X}$ may exercise over the assets of $\mathrm{ABCo}$, and the control which $\mathrm{X}$ would be able to exercise were they his personal assets, and he had no outstanding debt? ${ }^{152}$ If attention is directed to a more complex case, where entitlements are shared, then it becomes clear that there are of course differences in the way in which the 'balancing' strategies of property and organisational law are applied to different organisational forms-thus, the rules relating to corporate transactions, secured credit and insolvency in particular are different if the corporate form is used. However, these differences do not arise because a company has legal personality. Rather, they flow from nothing more than the fact that the strategies employed by the law for balancing the interests of third parties against those of insiders to the organisation are applied differently to organisations formed as companies. ${ }^{153}$ To emphasise this point, recall that under Scots law, a partnership has legal personality (whereas of course under English law it does not) yet no one suggests that because of this, the principles of agency or secured credit should apply differently north of the border. ${ }^{154}$

To say that corporate personality plays no part in an account of corporate law's function is not to say that the idea is a meaningless fiction. Rather, the role played by the notion of legal entity is a more subtle one. It affects not how the law

\footnotetext{
${ }^{152}$ It might be argued that the fact that a sole shareholder may be capable of being found guilty of theft where he takes corporate assets for himself, even with his own consent qua shareholder ( $A G$ 's Ref (No 2 of 1982) [1984] QB 624; $R$ v Philippou (1989) 89 Cr App R 290), would be a significant difference. However, both of these cases involved transfer of corporate assets to shareholders when the company in question was insolvent. If the company has and will have no creditors, then it is difficult to see how anyone could consider it dishonest (and hence for liability for theft to be an issue) for a sole shareholder to remove corporate assets for himself.

${ }^{153}$ As the point was more eloquently put by Hohfeld: '[w] hen all is said and done, a corporation is just an association of natural persons conducting business under legal forms, methods and procedures that are sui generis. The only conduct of which the state can take notice by its laws must spring from natural persons - it cannot be derived from any abstraction called the "corporate entity" (W.N. Hohfeld, 'Nature of Stockholders' Individual Liability for Corporation Debts' (1909) 9 Colum LR 285, 291).

${ }^{154}$ Partnership Act 1890 s 4(2).
} 
functions, but how lawyers think about the law. Arguably, 'corporate personality' provides a convenient shorthand for thinking about the combined effects of many of the foregoing property law mechanisms, which may act as a useful heuristic for judges and lawyers fleshing out the application of particular rules. ${ }^{155}$ This is, however, a quite separate issue from how the law functions in relation to business enterprise.

(b) The scope of 'corporate law'

One of the clearest implications of the analysis concerns the scope of what we think about as 'corporate law'. The subject tends to be seen as principally comprised of the rules described in the foregoing discussion as 'contractarian'. ${ }^{156}$ This is in part because rules of this type comprise the majority of the Companies legislation, ${ }^{157}$ in part because the very size of the subject makes it necessary to draw essentially arbitrary distinctions when writing books or designing courses and in part because knowledge of other relevant areas of law tends to be assumed on the part of students and practitioners of the subject. Yet with ever-increasing specialisation, there is a risk that with such boundaries come barriers to understanding, which are especially problematic if they are shared by law reformers. As the foregoing analysis demonstrates, it is only through the existence of a wide range of rules that are commonly classified under other headings-property law, agency, trusts, secured credit, insolvency - that the 'core' aspects of corporate law are able to do their work. Moreover, understanding and evaluating the way in which the law functions to facilitate and regulate the operation of business enterprise requires consideration of this whole range of doctrines. Our analysis suggests that the efficacy of the whole depends disproportionately upon the structure of the proprietary foundations, and in particular upon the way in which the essential strategies of property law are mixed together.

\section{Conclusion: Towards a Unified Theory of Corporate Law}

\footnotetext{
155 Whincop, above n 1, 46-47.

${ }^{156}$ See eg, Kraakman et al, above n 6, 15-17.

157 Thus, for example, it seems that the scope of 'core' company law as considered by the Company Law Review was largely determined by the scope of the existing companies legislation: see DTI, Modern Company Law for a Competitive Economy (London: HMSO, 1998), 17-18.
} 


\subsection{Contributions}

Economists seeking to explain the nature and scope of firms now attach as much significance to property rights as to contracts. In contrast, the regnant economic theory of corporate law is nevertheless still based upon a purely contractarian view of the firm. Taking seriously the importance of property rights requires corporate law theorists to understand the significance of property law's functions - in particular the facilitation of sharing of ownership rights between individuals-in supporting governance arrangements in firms.

A few scholars have already started to appreciate the significance of property law's contribution to the functioning of corporate law. Most notably, Hansmann and Kraakman have identified the importance of the way in which property law partitions assets between co-owners. This article makes three contributions to this emerging programme of research into the 'proprietary foundations' of corporate law. First, a link is established between the theory of the firm and the role of property law. The 'property rights' theory of the firm emphasises how entitlements to control assets can be used as governance mechanisms that complement incomplete contracts. However, it relies upon a simplistic conception of undivided ownership, which does not account adequately for the need, in all but the smallest business organisations, to have 'second order' arrangements that stipulate how the entitlements of 'ownership' in relation to assets are to be shared between participants. These sharing arrangements can themselves act as mechanisms of governance, and so it is valuable for parties to be able to customise them to suit their particular requirements, as by contract.

Yet the very sharing of ownership itself creates the possibility that a party with control for the time being might use it to grant entitlements in relation to the asset to a third party which are inconsistent with those of the other co-owners. If such transactions were effective, they (or the possibility thereof) could undermine the use of shared ownership as a governance mechanism. The law solves this problem by making the sharing arrangements enforceable not only as between the co-owners ('insiders' to the firm) but as against third parties generally. It is this function that forms the link between property law and the theory of the firm.

The law's protection of co-owners against each other's opportunism can, however, generate externalities - costs for unwitting third parties who incur losses in reliance on putative transactions. The second contribution of the analysis is to show 
that the law's function in relation to corporate enterprise is not simply to maximise the effectiveness of control-sharing arrangements between organisational participants by making voluntary agreements about control effective against third parties, but in so doing to trade off enforcement externalities, and the costs of administering the system. Three strategies are employed to effect this 'essential trade-off': (i) the use of a numerus clausus: that is, a fixed list of possible sharing arrangements; (ii) selective enforcement - only against third parties who are 'least-cost avoiders'; and (iii) mandatory registration of the existence or terms of such arrangements. A numerus clausus strategy severely limits the ability of co-owners to customise their arrangements, thus limiting their ability to design effective internal governance mechanisms. Both the selective enforcement and registration strategies are significant advances over this, for they allow co-owners to have contract-like flexibility over the terms of their sharing arrangements, whilst nevertheless giving these proprietary effect. The choice between registration and selective enforcement will depend primarily on the technology available for disseminating registered information to third parties.

Thirdly, to make the theory concrete, the article identifies the rules of English law that form the 'proprietary foundations' of corporate law. These are, in brief, the rules of agency and trusts law that support the delegation of ownership entitlements and the overreaching of property entitlements; and the laws of secured credit, fraudulent conveyances (transactions at an undervalue) and corporate insolvency that permit the sequential sharing of ownership entitlements between equity and debt claimants. The range of rules thereby included is, we consider, significantly broader than the notion of 'affirmative asset partitioning' developed by Hansmann and Kraakman. The basic strategies employed by these aspects of property law are a combination of a numerus clausus principle (for organisational forms and insolvency law) and selective enforcement (for agency transactions, equitable property rights, and fraudulent conveyances). Superimposed upon these in the context of corporate law is a set of registration requirements, and much of the complexity in this area of law has arisen from the way in which courts have sought to work out the appropriate interplay between these and the strategies already immanent in the law. Absent a technology for disseminating registered information at low cost to third parties generally, registration complements, rather than substitutes for, the other strategies of property law. 


\subsection{Implications}

Seeing corporate law in light of our theory generates a taxonomy that divides it into 'proprietary foundations' and a 'contractarian superstructure', which has several significant implications. As a matter of positive analysis, it points the way to overcoming some of the limitations of the purely contractarian theory of corporate law. The functions performed by the proprietary foundations of the subject could not be replicated by parties writing 'standard form' contracts, thereby responding to the objection of triviality. To be sure, our account does not deny that much of corporate law-the aspects we term the 'contractarian superstructure'-may usefully be analysed in contractarian terms. Nevertheless, it makes the positive claim that the successful operation of these rules depends upon the ability of property law to support the co-ownership arrangements that effect much of the internal governance of firms. On one level, our analysis can be seen as an attempt to re-emphasise the 'law' in corporate 'law and economics' scholarship. ${ }^{158}$ That said, we do not advocate any reification of the notion of the corporate 'entity'.

This positive claim yields empirically testable hypotheses. If we are correct, then the development of the 'proprietary foundation' of corporate law should be a much more significant determinant of capital accumulation than the rules comprised in the 'contractarian superstructure'. This could be tested both historically within a single jurisdiction and cross-sectionally over multiple jurisdictions. In particular, we would expect that (i) the efficacy of registration mechanisms; (ii) the availability of a general bona fide purchaser defence; and (iii) the effectiveness of insolvency law would be crucial for the development of corporate finance-more so than the introduction of the corporate entity principle itself.

Our account also has important normative implications. For those engaged in the reform of company law, the paper's analysis should assist in identifying which areas of law will yield the greatest return on the investment of reform effort. Resources should be concentrated on the law's proprietary foundation, since its impact is of disproportionate importance. Three specific implications are worth noting: (i) that reform of 'company law' should not be conducted in isolation from other areas of law that are important parts of the proprietary foundations of the

\footnotetext{
${ }^{158}$ See generally G. Hadfield and M. Richardson (eds), The Second Wave of Law and Economics (Leichhardt, NSW: Federation Press, 1999).
} 
subject, in particular secured credit and insolvency; (ii) that greater consistency could be achieved in the way in which the 'fundamental trade-off' is effected in relation to different aspects of corporate shared ownership; and (iii) the significance of information technology to the viability of the registration strategy. On this basis, the Law Commission's proposals for electronic registration of company security interests may well be the most significant part of the Company Law Review project. ${ }^{159}$ At the same time, it is to be lamented that the Review did not include corporate insolvency within its remit.

More generally, the analysis has implications for debates about the functions that company law should be understood as serving. Given that what we have termed the 'proprietary foundations' of corporate law cannot be replicated by private contract, it follows that no normative privilege should be accorded to private ordering in respect of this part of the subject. ${ }^{160}$ This is so, even for accounts internal to law and economics scholarship: it is quite possible that alterations in the way in which the proprietary foundations of corporate law effect the 'essential trade-off' could enhance efficiency. For example, it might be that introducing greater contractibility into aspects of the proprietary foundation that are currently governed by a numerus clausus strategy—such as insolvency law—might be a beneficial step. ${ }^{161}$ It is also conceivable that the facilitation of the grant of proprietary rights to other, noncreditor, stakeholder groups might also be welfare enhancing. ${ }^{162}$ These are difficult questions, answers to which are beyond the scope of this article. Our current point is simply that it cannot be presumed because such solutions do not currently exist, that they are not efficient.

\footnotetext{
${ }^{159}$ Above, n 150.

${ }^{160}$ Armour and Whincop, above n 123, 1000; T.W. Joo, 'Contract, Property and the Role of Metaphor in Corporation Law' (2002) 779, 816-820; Ireland, above n Error! Bookmark not defined.Errer!? Bookmark not defined.10, 503-509.

${ }^{161}$ See eg, A. Schwartz, ‘A Contract Theory Approach to Business Bankruptcy’ (1998) 107 Yale LJ 1807.

162 See J. Armour and S. Deakin, 'Insolvency and, Employment Protection: the Mixed Effects of the Acquired Rights Directive' (2002) 22 Int'l Rev. L. \& Econ. 443.
} 